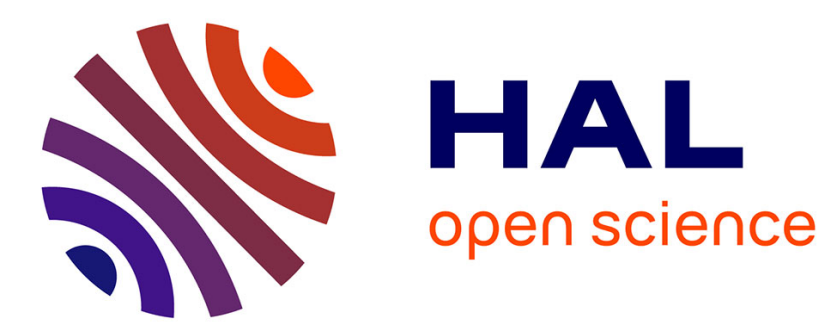

\title{
A Synthesis of the Effects of Exchange Rate Volatility on International Trade: A Meta-Regression Analysis
}

\author{
Jamal Bouoiyour, Refk Selmi
}

\section{To cite this version:}

Jamal Bouoiyour, Refk Selmi. A Synthesis of the Effects of Exchange Rate Volatility on International Trade: A Meta-Regression Analysis. 2016. hal-01880321

\section{HAL Id: hal-01880321 \\ https: / hal-univ-pau.archives-ouvertes.fr/hal-01880321}

Preprint submitted on 24 Sep 2018

HAL is a multi-disciplinary open access archive for the deposit and dissemination of scientific research documents, whether they are published or not. The documents may come from teaching and research institutions in France or abroad, or from public or private research centers.
L'archive ouverte pluridisciplinaire HAL, est destinée au dépôt et à la diffusion de documents scientifiques de niveau recherche, publiés ou non, émanant des établissements d'enseignement et de recherche français ou étrangers, des laboratoires publics ou privés. 


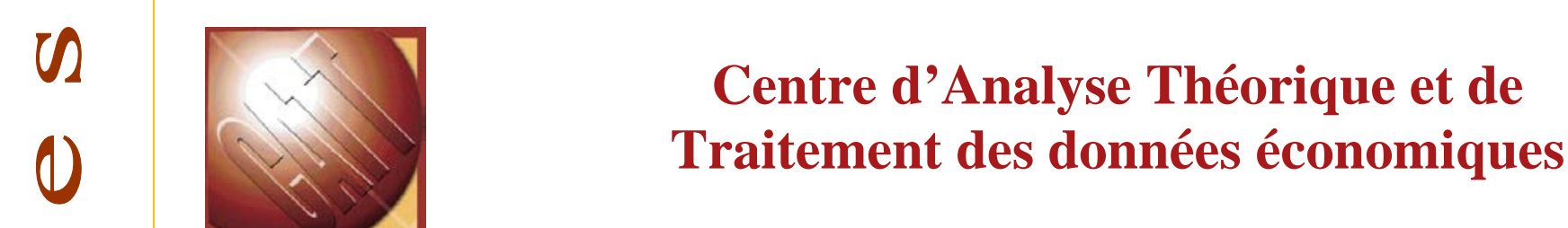

0

\section{CATT WP No. 10}

June 2016

A SYNTHESIS OF THE EFFECTS OF EXCHANGE RATE VOLATILITY ON INTERNATIONAL TRADE: A META-REGRESSION ANALYSIS

Jamal BOUOIYOUR

Refk SELMI 


\title{
A Synthesis of the Effects of Exchange Rate Volatility \\ on International Trade: A Meta-Regression Analysis ${ }^{1}$
}

\author{
Jamal BOUOIYOUR \\ University of Pau, France \\ Email: jamal.bouoiyour@univ-pau.fr \\ Refk SELMI \\ Business School of Tunis, Tunisia \\ Email: s.refk@yahoo.fr
}

\begin{abstract}
This paper surveys literature that investigates the effects of exchange rate uncertainty on international trade. We perform meta-regression analysis on 41 studies with 807 estimates. We show that the empirical works exhibit substantial publication selection and show a significant genuine exchange rate volatility effect on trade flows after correction of publication bias. In addition, the literature reveals a pronounced heterogeneity with respect to model specifications, samples, time horizons, and countries characteristics. The results appear robust among the different estimators and to the inclusion of dummies for the type of research outlet and publication year. These findings are supported by separate assessment of primary studies with, respectively, total exports and sectoral exports as the dependent variable. In comparison with the sectoral exports literature, the total exports literature seems more homogenous and its identified exchange rate volatility effect on trade is less conditional. In general, our most important advice for policy makers is that economic research does not reveal a single representative effect size.
\end{abstract}

Keywords: Exchange rate volatility; international trade; meta-regression analysis.

\footnotetext{
${ }^{\mathbf{1}}$ The authors are greatly indebted to the anonymous referee for his/her many helpful comments and for giving us the opportunity to explain some key features of our empirical strategy. We thank the editor for the excellent advices we have received. Remaining shortcomings are the responsibility of the authors.
} 


\section{Introduction}

The effect of exchange rate uncertainty on international trade has been, and continues to be, a highly debated topic. Since the breakdown of the Bretton Woods system of fixed exchange rates, both real and nominal exchange rates have fluctuated substantially. These sizable fluctuations are often seen as detrimental and may inevitably create uncertainty in the development of macroeconomic policies, investment decisions, and international trade flows. Furthermore, an increase in exchange rate instability leads to substitution, which encourages traders to choose internal trade instead of foreign trade, and income consequences, which may increase trading activities, since a higher exchange rate risk gives greater opportunities to gain profits and improve trade performance.

Since 1973 several countries have adopted the floating exchange rate system in order to enhance their export competitiveness. This transition, accompanied with a boom and bust in commodity prices, intensified the volatile behavior of exchange rates, increasing the uncertainty surrounding international trade and threatening economic growth. The increase in volatility caused by transitioning to the floating exchange rate system may exacerbate a disconnection between exchange rates and their main determinants making it very difficult to cope with possible attacks that heavily characterize international markets, especially in countries with inefficient financial systems. The absence of hedging instruments, due to their costs, can also result in fluctuations of the exchange rate, which may have a harmful impact on trade. The complex nature of this volatility and possible effects, the strong asymmetry of price cycles, and the high persistence of shocks have contributed widely to the plethora of studies analyzing the empirical connection between exchange rate uncertainty and international trade.

The literature on the focal issue is inconclusive. Some studies have supported a negative effect of exchange rate volatility on exports and linked it to the imperfect markets 
and the cost of hedging (Kumar and Dhawan 1991; Arize 1996; Arize et al. 2000; Véganzonès and Nabli 2002; Clark et al. 2004). Other studies have shown that higher exchange rate instability can give opportunities leading to an increase of trade flows, especially when exporters are sufficiently risk-averse (Hooper and Kohlhagen 1978; Abbott et al. 2001; Cheong et al. 2002; Bredin et al. 2003; Olimov and Nishanbay 2008). Some even provide evidence that exchange rate uncertainty may have no significant effect on foreign trade (Franke 1991; Aristotelous 2001; Achy and Sekkat 2001; Bouoiyour and Selmi 2014 a). Thus for the past thirty years, the empirical literature has reinforced the theory that there is an ambiguous link between exchange rate volatility and exports. However, the results of these studies vary depending on the level of development in the countries included in the data set and differing estimation methods used by researchers.

The primary goal of this article is to apply a meta-regression analysis (MRA) to tackle the causes behind the heterogeneity of the results and to accurately estimate the trade effect of exchange rate volatility. Haile and Pugh (2011, pp.3) claim that "MRA can improve the estimation of the parameter of interest by filtering out any publication bias, and by explaining heterogeneity in the results of previous studies”. In particular, this study conducts two metaregression tests: the funnel asymmetry test (FAT) to detect publication selection; and the precision effect test (PET) to test for a genuine effect beyond publication (selection) bias. This paper not only replicates Ćorić and Pugh (2010) and Haile and Pugh (2011) but also intends to extend them in two main ways: by substantially enlarging the data $\operatorname{set}^{2}$; and by using

\footnotetext{
${ }^{2}$ For Ćorić and Pugh (2010), the database includes the empirical studies published between 1978 and 2003, whereas Haile and Pugh (2011) restricted the data-set to observations from econometric papers published after 1990. However, for our case, we used extensive searches on Google Scholar and on databases such as EconLit and Web of Sciences to identify as far as possible a complete population of published empirical works that examine the exchange rate volatility effects on international trade. In particular, we perform a meta-regression analysis using data from published works between 1978 and 2014. While Ćorić and Pugh (2010) used several Keywords in the search "exchange rate instability", "exchange rate variability", "exchange rate volatility", "exchange rate uncertainty" and "trade effect", this study used three main search queries "exchange rate volatility", "exchange rate uncertainty" and "international trade effect".
} 
further relevant moderator variables. In particular, a multivariate MRA was performed, enabling us to make a novel and substantial contribution to the literature while trying to identify additional sources of heterogeneity in the policy context of the primary studies. Unlike Ćorić and Pugh (2010) and Haile and Pugh (2011) which conduct a mainstream MRA without augmenting their models with contextual variables, in this study, we extend our metaregression analysis database with variables capturing "financial development”, "exchange policy”, monetary policy” and "trade policy”. The extension of Ćorić and Pugh (2010) and Haile and Pugh (2011) provides a strong robustness check on their results and better paths into why the empirical literature on the relationship between exchange rate volatility and trade is so heterogeneous in its findings.

Our quantitative survey reveals that an adverse effect of exchange rate volatility on trade is conditional on heterogeneities with respect to model specifications, samples, datasets, time horizons and distinct countries characteristics (the degree of oil dependency, the efficiency of financial systems, the use of anti-cyclical or countercyclical price policy, or if the country is a price taker or price maker). The focal relationship is potentially influenced by the choice of dependent variable. In particular, these findings are supported by separate investigation of primary studies with, respectively, total exports and sectoral exports as the dependent variable. We also show that substantial publication selection bias exists towards a positive impact of exchange rate uncertainty on trade. These results seem robust among the different estimators used, and the inclusion of dummies for the type of research outlet (i.e., working paper or publication in academic journal), and the publication year included in the estimates.

The structure of the paper emerges along the following lines: section two reviews the main empirical studies concerning the effects of exchange rate volatility on international trade, presents the construction methodology of our meta-data set and describes the meta- 
analysis estimation method employed. Section three presents the empirical results and discusses them, and section four summarizes our main findings and concludes the paper.

\section{Review of the literature and construction of meta-sample}

Section 2.1 presents a review of empirical studies on the effects of exchange rate volatility on trade. Section 2.2 describes accurately how we proceeded in order to construct the meta-sample which in turn served as a basis for our meta- regression analysis.

\subsection{Review of literature}

Since the onset of generalized floating, international economists have long debated the likely impact that exchange rate uncertainty has on international trade, but the varied results have given no thorough guidance on this relationship. Although there are many studies on how exchange rate instability interacts with trade (for instance, McKenzie and Brooks 1997; McKenzie 1998; Arize et al. 2000; Aristotelous 2001; Vergil 2001; Rey 2006; Égert and Morales-Zumaquero; Bouoiyour and Selmi 2014 a, etc.), the obtained evidence is mixed.

The empirical literature may be synthesized into three main categories. The first and largest category shows a negative effect of exchange rate volatility on international trade. Dell'Arricia (1999) and Kumar and Dhawan (1991) found that uncertainty surrounding exchange rates lessen the volume of trade flows, but they also noted that "perfect forward markets” may mitigate the possible harmful effects of this great volatility on international trade. Pozo (1992) found that uncertainty with respect to exchange rate variations over long periods of time threaten the performance of total and sectoral exports. Accordingly, Lee (1999) and Lee and Saucier (2005) associated this negative connection to imperfect markets and to high hedging costs. Others argue that exchange rate volatility can be hedged through effective financial instruments, such as exchange rate derivatives. For example, Dohring 
(2008) asserts, "these instruments can be considered as standard tools for hedging risks related to exchange rates or commodities prices”. Significant exchange rate volatility may be mitigated by a well-developed financial system and hedging tools, since this allows firms to avoid negative shocks and speculative attacks (Arize et al. 2000; Vergil 2001; Sauer and Bohara 2001). Unfortunately, it is difficult for developing economies with weaker financial systems to avoid the detrimental effects of sudden shocks and short-run disturbances (Frankel and Rose 2000; Véganzonès and Nabli 2002; Kandilov 2005). One of the main motivations behind the literature in this category was the theory that in the absence of an efficient financial system and effective anti-cyclical price policy, trade would be threatened by the excessive exchange rate volatility (Cheong et al. 2002; Clark et al. 2004; Sadikov et al. 2004; Bouoiyour and Selmi 2014 b, c).

Since some studies support the view that exchange rate instability may increase trade flows (McKenzie and Brooks 1997; Fountas and Aristotelous 2003), the second category relies on the positive link between exchange rate uncertainty and trade. Abbott et al. (2001) find that if exporters are sufficiently risk-averse, exchange rate uncertainty affects their trade favorably. Consistently, Haile and Pugh (2011) show that "under general conditions, a risk neutral exporting firm increases its trade with increased exchange rate instability.” Moreover, Stockman (1995) argued that exchange rate uncertainty expands the probability that export pricing costs exceed production prices, concluding thus that the instability of the exchange rate may strengthen the performance of international trade.

The third category found in a small number of studies, reveals that in the agricultural sector, exchange rate uncertainty has no significant effect on international trade (such as Franke (1991) and Achy and Sekkat (2001)). To explain this result, Égert and MoralesZumaquero (2007) and Bouoiyour and Selmi (2014 d) assert that a high degree of competitiveness in one sector decreases vulnerability to exchange rate volatility. Specifically, 
if a country is a price maker (i.e., it plays an important role in setting its own prices in international markets), its economy may recover quickly after a crisis and better cope with external shocks. Diversification may also considerably reduce the potentially damaging effects of exchange rate uncertainty on exports (Clark et al. 2004). Another explanation for the evidence that exchange rate uncertainty has no significant effect on international trade may be linked to the studied sector itself. For example, despite the boom-bust of primary commodity prices and the greatly volatile behavior of exchange rates, the exporters of agricultural products (“perishable” products) generally have a neutral attitude towards risk (Achy and Sekkat 2001; and Bouoiyour and Selmi 2014 b). The lack of a significant connection between the two variables may also be a reflection of "the presence of sunk cost in exporting” (Franke 1991); that is to say, the more important the trade costs, the less sensitive exporters will be to exchange rate uncertainty.

Clearly, the macroeconomic literature debates the link between exchange rate uncertainty and trade and encompasses a variety of countries and several econometric methods, making it difficult to reach solid and unambiguous conclusions (Pugh et al. 2012). Moreover, in the existing literature, there are few studies that assess this "complex" relationship in nonlinear or asymmetrical fashions. For instance, Bouoiyour and Selmi (2014 a) examined whether there is a nonlinear dynamic interaction between exchange rate volatility and exports in Egypt. Their study relied on an optimal GARCH model chosen using information criteria on decomposed series on a scale-by-scale basis (i.e., wavelet decomposition). Their results show that the connection between exchange rate uncertainty and trade flows depends substantially on scale-by-scale variations (i.e., a nonlinear relationship) and slightly on the leverage effect (i.e., an asymmetrical relationship). Additionally, they argue that the correlation is stronger at a low frequency than at a high frequency. Other studies using asymmetrical GARCH models to measure volatility (Lee and Saucier 2005) 
reveal that there is a significant leverage effect on volatility, and thus, exports may respond positively to exchange rate depreciations and negatively to appreciations.

Little research exists that accounts for cyclicality when assessing the effects of exchange rate uncertainty on exports. Bouoiyour and Selmi (2014 d), for example, used frequency approaches over the period 2000q1-2015q1 to address interactions between exchange rate (nominal exchange rate and differential price), exports and energy in Russia, even if they incorporate potential control variables. By doing so, they show that the effect of differential price on exports is stronger than that of nominal exchange rate. These connections decrease slightly when subtracting energy's share from total exports. However, either with or without energy, both interdependence and causality seem highly supported in the long-run. Their results suggest that the problem of Russia's exports is likely to be endogenous (the great energy dependency, the lack of direction diversification, the loss of price competitiveness and the tension between stabilizing price and exchange rate) rather than exogenous (the speculation and the world demand).

\subsection{Meta-data set and methodology}

Since several findings in the literature are inconclusive, meta-analysis, a statistical technique that combines different results from independent studies, is helpful in reconciling inconsistencies (Stanley 2005). Its validity depends on the quality of the systematic review on which it is based. The goal of our meta-analysis is to examine all heterogeneity in order to highlight the main factors behind the controversial link between exchange rate uncertainty and international trade. Specifically, we employ meta-regression analysis to investigate whether publication selection bias exists by studying variations in a diverse sample of previous empirical studies. Publication bias may arise when editors or referees accept 
significant findings that satisfy their theoretical expectations and reject insignificant or unexpected results (Stanley 2008).

Throughout the rest of this research, we collect empirical works that assess the focal relationship between exchange rate volatility and international trade. The database for the analysis has been constructed based on several published empirical papers on this topic, which we collected using Econlit and the Google Scholar search engine. Table 1 lists the 41 studies employed in our analysis as well as some descriptive statistics concerning the estimated coefficient of the size effect of exchange rate volatility on exports. As is the norm in meta-analysis, we excluded non-empirical studies on this issue, following Stanley (2001) and Doucouliagos and Laroche (2009). Since each study reports several estimations, we follow Doucouliagos and Stanley (2009) and report them all as independent regressions and thus our meta-sample includes 807 observations. It can be easily seen from Table 1 that there exist a huge variation among the empirical studies. First, the number of coefficients obtained from each study ranges significantly. That is, although we obtain a relative large number of observations from some studies (Kandilov (2005) with 225 reported coefficients and Égert and Morales-Zumaquero (2007) with 100 coefficients, for instance); others contribute by displaying a small number of estimated coefficients (for example, Pozo (1992) and Stockman (1995) with 2 and 6 reported coefficients, respectively). In addition, there exists a sharp variation in the mean value of coefficients (descriptive statistics, column 3, Table 1), ranging from a value of -2.080 (Chit and Judge 2011) to 608.275 (McKenzie and Brooks 1997).

A simple meta-analysis model consists of regressing the reported estimated coefficient of each study (i.e. the estimated effect of exchange rate volatility on exports) weighted by its standard error (i.e., the t- statistic ${ }^{3}$ of each study) over an intercept and the inverse of the

\footnotetext{
${ }^{3}$ We follow Jarrell and Stanley's (1990) recommendation that in economics the t-value of the regression coefficient is the natural effect size. Based on each finding reported in each study, the t-value of the estimated coefficient measuring the trade effect of exchange rate volatility was chosen as the effect size.
} 
standard error of the coefficient (Adam et al. 2013; Benos and Zotou 2014). In particular, we use the t-statistic from each regression result as the exchange rate volatility effect size throughout this article. It must be stressed here that the variables are weighted with the standard error in order to correct the meta- regression model for its built-in heteroskedasticity problem (Stanley 2008).

To explain the heterogeneity of the results in this literature, various moderator variables were selected and incorporated in the meta-regression analysis. These moderator variables reflect the main data, model specifications used and additional contextual variables for each regression finding. A comprehensive list of the moderator variables required for this meta-regression was identified. Table 2 defines the relevant moderator variables identified for the purpose of the present meta-regression analysis. In accord with our intention to replicate and to extend Ćorić and Pugh (2010) and Haile and Pugh (2011), we use, in addition to the nature of countries and the modeling strategies, further potential moderator variables capturing the degree of financial development, the exchange rate policy adopted and the monetary and trade policies pursued. Table 2 indicates the vast range of empirical approaches followed by the 41 studies that provide the data for this meta-regression analysis. We integrated variables we expected to have a systematic influence on the exchange rate volatility effects on international trade. The moderator variables are dummy variables that are grouped into contextual features of the model. For instance, the dependent variable measures trade flows between developed (DC*) and developing economies (DC); economies with welldeveloped financial system (DFS) and inefficient financial development (IFS); price makers (PM) and price takers (PT); oil dependent economies (OD) and non OD economies; and whether the study does or does not account for nonlinearity (NL) and asymmetry (AS). The thought behind nonlinearities can be explained by the fact that exporters will not alter their prices in reaction to exchange rate changes in case the exchange rate returns to its previous 
value. In particular, this explanation holds in times of swelling exchange rate volatility (Verheyen 2013). An element that may be in the favor of asymmetry in the interaction dynamic between exports and exchange rate volatility is that exporters could react differently to appreciations and depreciations. If exporters attempt to maintain market shares, appreciations could be absorbed at least partly in exporters' margins and as a result an appreciation would not affect exports as heavily as one might expect (Bouoiyour and Selmi 2014 b). This is done without neglecting the "pulling” effects of models used (i.e., "naïve models" (NM) where the historical variance is used as the variance estimator or "sophisticated techniques” (GM) such as asymmetrical GARCH models, nonlinear GARCH extensions, time-varying GARCH technique, and component GARCH with threshold orders are used to measure volatility). Together, the moderator variables allow us to use meta-regression analysis to examine their influence on the estimated effect size of different countries (in terms of the degree of financial development, the exchange regime adopted, the monetary policy, the trade policy, and the degree of oil dependency) and econometric methods. Additionally, we used the earliest and latest year of the sample in the considered studies (i.e., a test-dummy variable presenting the publication year ${ }^{4}$ for each study (PUBY)) to see whether the sample period significantly affects the estimated exchange rate uncertainty coefficient. Based on Adam et al. (2013) and Benos and Zotou's (2014) studies, we include a dummy variable to

\footnotetext{
${ }^{4}$ Several studies have asserted that the strength of findings has significantly changed with year of publication (Alatalo et al. 1997; Gontard-Danek and Møller 1999; Poulin 2000). Simmons et al. (1999) argued that, during the initial stages of research in particular area, it might be easier to publish confirmatory results than later on when a more critical view of the focal issue develops. For our study, we incorporated additional moderator variables in order to evaluate if specific characteristics of empirical approaches explain the variation in our results. These variables were chosen on the basis of recent literature concerning the importance of each variable (Adam et al. 2013; Benos and Zotou 2014). In particular, the full set of moderator variables includes variables that take into account the structure of the dataset or more precisely the earliest and latest year while attempting to explore whether the sample period influences the estimated exchange rate volatility's coefficient due to structural change.
} 
analyze if a study published in an academic journal (AJ) may influence the variation of the reported findings.

Meta-regression analysis enables us to synthesize distinct findings in a common framework (Harmon et al. 2003). We started by using the following model:

$$
\beta_{i}=\beta_{0}+\alpha_{k} Z_{i k}+\beta_{1} s e_{i}+u_{i} ; i=(1, \ldots, 41)
$$

Here $i$ indexes the regressions in the MRA database. $\beta_{i}$ is the reported estimate of exchange rate volatility coefficient of the $i^{\text {th }}$ study, $\beta_{0}$ is the value of the volatility of the exchange rate coefficient, $Z_{i k}$ are the moderator variables that influence the magnitude of the published results and explain variations in coefficients $\beta_{i}$ (i.e., Equation (1) is a multivariate regression model that includes different meta-independent variables), $\alpha_{k}$ are the meta-regression coefficients that reflect the effect of specific study characteristics, $s e_{i}$ is the standard error of the coefficient of the $i^{\text {th }}$ study, and $u_{i}$ is the meta-regression disturbance term. In the presence of publication selection, authors of studies with small sample sizes tend to select large and significant effects to mitigate their less accurate estimates. Thus the statistical significance of $\beta_{1}$ can be an indicator for publication selection bias (Stanley 2005; Adam et al. 2013). Furthermore, MRA evaluates the extent to which statistical heterogeneity of the empirical outcomes can be related to characteristics across multiple studies. It is difficult to fully explain the heterogeneity in the observed results, hence there will be "residual heterogeneity" (Benos and Zoutou 2014).Generally speaking, the empirical works use different sample sizes and econometric methodologies, implying that $u_{i}$ in the equation (1) is likely to be heteroscedastic. Given this, the estimation of equation (1) may not be proper and effective. Because the variances are well known, the weighted least squares (WLS), obtained by dividing equation (1) by $s e_{i}$, may be close and more appropriate to estimate the between-study variance. 


$$
t_{i}=\beta_{1}+\gamma_{i} K_{i}+\beta_{0}\left(1 / s e_{i}\right)+\sum_{i=1}^{k} \alpha_{k}\left(1 / s e_{i}\right) Z_{i k}+v_{i}
$$

In this equation, $t_{i}$ is the t-statistic that corresponds to the estimate $\beta_{i}$. Because publication selection remains a deeply complex phenomenon, in this equation we have replaced the coefficient $\beta_{1}$ in equation (1) with $\left(\beta_{1}+\gamma_{i} K_{i}\right)$, where $K_{i}$ are political-economic variables heavily correlated with the publication process (Doucouliagos and Stanley 2009). $\beta_{0}$ corresponds to the value of the exchange rate volatility coefficient, and $\alpha_{k}$ are the metaregression coefficients reflecting the impact of specific characteristics on the considered studies. As mentioned above, $Z_{i k}$ are the meta-independent variables that may explain the variation in coefficients $\beta_{i}$, and $U_{i}$ is the weighted error term $\left(u_{i} / s e_{i}\right)$ where $s e_{i}$ is the standard error of the coefficient of the $i^{\text {th }}$ study. Equation (2) is a multivariate regression model with inversed moderator variables. This specification may be useful for testing for the existence of publication selection bias and the impacts of exchange rate volatility on trade flows corrected for publication selection. We can employ, for instance, the Funnel Asymmetry Test (FAT) to properly test for publication bias (Benos and Zotou 2014).

Although policy discussions appear to be guided by a belief that pegged exchange rate regimes enhance international trade, the research literature fails to reach firm evidence in this regard. Some studies showed that exchange rate volatility negatively affects international trade flows (for instance, McKenzie 1999; Cheong et al. 2002; Bredin et al. 2003, among others). Others argued that the effect of excessive exchange rate variability on trade is likely to be positive (for example, Hooper and Kohlhagen 1978; Arize 1996; Arize et al. 2000; Clark et al. 2004, etc...). Meta-regression analysis examines the extent to which statistical heterogeneity between results of these multiple studies can be related to one or more characteristics of the studies. It is very unlikely that overall heterogeneity will be explained; hence, there will be "residual heterogeneity", highlighting that random effects seems more 
appropriate than fixed effects meta-regression. Basically, the algorithms for random-effects meta-regression initially estimate the between-study variance and then estimate the coefficients by weighted least squares. Normally, accurate studies have more weight in the analysis. In our case, the between-study variance represents the excess variation in exchange rate volatility effects on trade that is expected from the imprecision of results within each study. In that context, different econometric techniques have been proposed for the estimation of the between-study variance in meta-regressions. For example, the unknown variance of the random-effect model can be computed by an iterative residual (restricted) maximum likelihood process (REML), the Empirical Bayes (EB) method (Thompson and Sharp 1999), or a moment estimator (MM). In computational viewpoint, the likelihood approaches are seemingly restrictive and vulnerable since they become intensive and time consuming as the number of studies increases. To overcome the downward biased estimates of the betweenstudy variance, the REML appropriately underestimates standard errors and the anticonservative inference (Adam et al. 2013). The MM estimator has the advantages of speed and robustness since it has no iteration requirements and outperforms likelihood techniques with simulated and real data sets (Mavridis and Salanti 2012). Furthermore, the empirical Bayes is useful in the context that information from historical data can be easily included in the model through informative priors (Benos and Zotou 2014). Ultimately, because the majority of researches in our sample report more than one regression, it is likely that observations -i.e., exchange rate volatility’s coefficients- are correlated within studies. Given this, employing OLS with heteroskedasticity cluster-robust standard errors may also be appropriate, which would enable us to identify an error term correlation within each cluster. This last method is used in our study as a benchmark, because it is the simplest one and is used in a huge number of meta-regression studies (Doucouliagos and Stanley 2009; Effendic et al. 2011, for instance). 


\section{Meta-regression results}

\subsection{Publication selection bias}

Publication selection bias has been one of the most important concerns amongst metaanalysts since most academic journals are more likely to publish research that report significant and expected outcomes. Publication bias occurs when the considered meta-data have similar results or when researchers have an incentive to conform. For example, if a study suggests a positive or insignificant relationship between two variables and the majority of works on the same field show a negative and significant link, it is unlikely that the study claiming a positive link will be accepted by editors or referees for publication (Bom and Ligthart 2008; Pugh et al. 2012). As a result, researchers may choose not to submit unconventional findings, and the empirical literature on the issue may be affected by publication bias (Bouoiyour et al. 2014). In addition, research based on a small sample is usually at a disadvantage in reaching statistically significant findings, since limited degrees of freedom are closely associated with wide standard errors on estimated coefficients. For this reason, authors that have small sample should generally search more (estimators; methods; data sets; proxies; among others) to find significant outcomes, which per se makes publication bias more likely (Effendic et al. 2011). Fortunately, MRA researchers have developed a proper methodology for detection of publication (selection) bias (Stanley 2005; 2008). In light of this, we decided to test for publication bias in the existing literature on the relationship between exchange rate volatility and trade.

To achieve this goal, one possible tool available to us was a funnel plot: a simple method often used to detect selection bias (Jarrell and Stanley 1990; Doucouliagos 2005). It depicts the estimates of exchange rate volatility coefficients on the X-axis (horizontal) and the inverse of their standard errors on the Y-axis (vertical). In the absence of publication bias, the considered works will be distributed randomly and symmetrically around the combined effect 
size. By contrast, in the presence of bias, it would show a higher concentration of studies on one side of the mean than on the other. Figure 1 clearly indicates that the plot is heavily weighted on the right side, implying the presence of publication bias towards positive values of the impact of exchange rate uncertainty on trade flows. Although this visual examination was useful, the funnel plot is considered a "subjective test” for analyzing publication selection (Benos and Zotou 2014) and cannot be the sole evidence of publication bias and authentic effects. We turned thus to "formal and objective statistical tools" that allowed us to better test for capturing effectively any publication selection in the research literature. For this purpose, we explore a model for meta-regression analysis that provides the framework for properly identifying and correcting the effects of publication bias. To establish that the results are not plagued with publication bias, based on the studies of Stanley (2008), Effendic et al. (2011), Adam et al. (2013) and Benos and Zotou (2014), we employed the Funnel Asymmetry Test (FAT) and the precision-effect Test (PET) simultaneously (Equation 2) to test for the presence of publication (selection) bias.

Together, these tests assume that $\alpha_{k}$ and $\gamma_{i}$ in Equation (2) are zero. In other words, there is no heterogeneity effect. To perform the FAT-PET test, we estimate the following equation:

$$
t_{i}=\beta_{1}+\beta_{0}\left(1 / s e_{i}\right)+\xi_{i}
$$

In which $t_{i}$ refers to the t-value of the estimated coefficient on the exchange rate volatility measure from the $i^{\text {th }}$ regression results, $\beta_{0}$ and $\beta_{1}{ }^{5}$ are coefficients to be estimated, the inverse of $s e_{i}$ is the independent variable, and $\xi_{i}$ is the weighted error term. Normally, if there is no publication bias in the concerned studies, the intercept term will not be significant (i.e., we accept $\mathrm{H}_{0}: \beta_{1}=0$ ). In contrast, a non-zero intercept term implies an upward or downward

\footnotetext{
${ }^{5}$ These two coefficients together provide the basis for the FAT-PET testing procedure for the presence of publication bias and the genuine empirical effect (Doucouliagos and Stanley 2009; Stanley and Doucouliagos 2012).
} 
publication selection bias on the estimated effects reported in the literature. In our case, the FAT test revealed that publication bias exists (Table 3), because the constant term was statistically significant for all considered estimators. Moreover, the test tells us that it is an upward publication bias because $\beta_{1}$ seems positive and is greater than 1 and less than 2 (Stanley and Doucouliagos 2012). Lastly, because the coefficient $\beta_{0}$ is considered a proper estimate of the effect corrected for publication selection, this model was also used to determine whether there is a genuine effect beyond the publication selection. MM technique's outcomes (Table 3) reveal that there is no evidence of a genuine exchange rate uncertainty effect on international trade. However, the findings obtained through the rest of the methods (i.e., cluster data analysis, REML and EB) suggest exchange rate volatility has a positive genuine effect on exports; however, this effect appears small in all cases.

Recall that a bivariate MRA estimate may lead to erroneous outcomes when important independent variables are omitted (Doucouliagos and Stanley 2009). Accordingly, we performed a multivariate meta-regression model, in which "FAT" and "PET" tests are embedded (Stanley 2008), to control sources of heterogeneity in the literature, as well as their consequences, for the estimated impacts of exchange rate volatility on international trade flows. For this purpose, the moderator variables listed in Table 2 model the impacts of distinct specifications, samples, time-horizons observed, methodologies and policy proxies. After controlling for these effects, we are able to test for publication bias and for the presence of an authentic empirical effect in the literature. More precisely, the empirical effect is measured conditioning upon the sources of heterogeneity identified in the MRA.

\subsection{Effects on exchange rate volatility coefficients}

Our meta-regression analysis started by incorporating the potential moderator variables listed in Table 2 (Equation (1)) and then dividing the equation (1) by the standard 
error (i.e., all meta-independent variables are weighted by the inverse of $s e_{i}$ ). This allows us to avoid possible estimation bias from omitted variables and create an accurate framework to explain the large variation in reported effect sizes. Since the inverse of $s e_{i}$ interacted with the moderator variables in the multivariate model, it is the combination of all the explanatory variables that captures the size of the "authentic empirical effect" (Haile and Pugh 2011; Stanley and Doucouliagos 2012). The F-test reported in Table 4 suggests that all the considered meta-independent variables are jointly statistically significant $(\mathrm{p}=0.0863)$, underscoring the existence of a genuine empirical effect beyond publication bias.

Haile and Pugh (2011) meta-regression analysis differs from the strategy followed in this article. Although the exchange rate volatility's effect size is the same (i.e., t-statistic on the estimated coefficient of interest in each regression reported in the literature), it was not derived from the PCC as the primary effect size but, rather, was chosen in ad hoc manner (as in Adam et al. 2013; Benos and Zotou 2014). The following discussion and interpretation of our results draws on Table 4 (MRA considering working papers and publications in academic journals) and Table 5 (MRA with dummies for publication in academic journals and the publication year). For all cases, the Ramsey RESET test results do not reject the null hypothesis that there are no omitted non-linear terms. In other words, from the perspective of the RESET test, the models used are valid. Although the moderator variable for research focusing solely on bilateral exports (BEXP) is not statistically significant, the consistently negative coefficient estimate for total exports (TEXP) and sectoral exports (SEXP), that highlights the importance of dividing the overall sample into three sub-samples (TEXP, SEXP and BEXP) to find better paths in terms of the relationship between exchange rate volatility and international trade.

With studies of nominal exchange rate volatility (NT) as the reference category, the empirical works that regress exports on the real exchange rate variability (RT) typically 
display less positive effects of exchange rate volatility on international trade. Since it is only over long periods that real exchange rate volatility diverges from its nominal value, the negative coefficient associated to RT dummy corroborates the view that forward markets have a "pulling” role in mitigating the detrimental effects of sizable exchange rate variability on trade (Haile and Pugh 2011). These results are solid among the different estimators, except the empirical Bayes iterative procedure (EB).

The negative coefficient estimate for trade among less developed countries (DC), the price takers (PT) coupled with anti-cyclical price policy (ACP), and inefficient financial system (IFS) is further evidence of how important the forward markets are in minimizing the volatile behavior of exchange rates. Generally, less developed countries are distinguished during the absence of forward markets. This with imperfect capital mobility drops the possibility of hedging against swelling volatility in these countries (Gervais et al. 2004; Ćorić and Pugh 2010; Haile and Pugh 2011). The findings indicate also that monetary and fiscal policies explain significantly the reaction of trade to exchange rate volatility. Expectedly, following appropriate policies may greatly help absorb external shocks and avoid great speculation (Bahmani-Oskooee and Payesteh 1993).Together, these outcomes are partly consistent with the suggestion of Corić and Pugh (2010) and Haile and Pugh (2011) that an authentically adverse exchange rate volatility effect on trade is most likely to be discovered when the literature examines trade that takes place beyond the reach of forward markets and well developed financial systems; however, we add the effectiveness of anti-cyclical price policy and the position of country as price maker (PM). This interpretation is supported by the statistically significant negative coefficient on the dummy variable for studies of the impact of annual exchange rate volatility (low frequency, LF). Compared to high frequency (HF) variability (quarter-to-quarter variation is the benchmark), year-to-year variability is less 
subject to hedging. This confirms the idea that forward markets are essential in lessening the volatile behavior of real exchange rates.

Our study suggests also an exchange rate regime effect whereby exchange rate volatility under pegged exchange rates (PER) may have a different influence on trade than exchange rate variability does under floating exchange rates (FER). However, the sign of the coefficient associated to the moderator variable PER is not fairly robust among the different estimators used (cluster data analysis, REML, MM, and EB, Table 4); we note this regime effect is not solid, consistently with Haile and Pugh's (2011) suggestion. Not surprisingly, under floating exchange rate regime, the nominal exchange rate may be the main determinant of real effective exchange rate variation. On the other hand, in a pegged exchange rate regime where the nominal exchange rate moves into a target, the inclusion of the differential price volatility seems legitimate (Égert and Morales-Zumaquero 2007; Bouoiyour and Selmi 2014 a, b). What is new here compared to Ćorić and Pugh (2010) and Haile and Pugh (2011) is that trade policies may play a significant role on the effect of exchange rate volatility on international trade. While the estimated effect of global trade agreements (GTA) is to make the effect of exchange rate variability on exports more negative (or less positive), we note that a regional trade agreement (RTA) makes the effect less negative (or more positive). We can thus deduce that trade policies pursued explain some of the variation in the present empirical literature.

The choice of empirical strategies also explains some of the heterogeneous findings in the existing literature. In Table 4, the coefficients measuring the effect of cross-section estimations (CROSS) and standard OLS technique (OLS) tend to favour the discovery of adverse trade effects. Moreover, the volatility proxies may also heavily explain the heterogeneity in this empirical literature. Unlike the study of Haile and Pugh which uses GARCH models as measures of volatility, we distinguish between "naïve” models (NM) and 
"sophisticated" techniques or more precisely the conditional variance calculated using different GARCH models (GM) ${ }^{6}$. In Table 4, the coefficients measuring the effect of GM are statistically negative across the different estimators applied. Nevertheless, the coefficients associated to "naïve" models display variant effects on trade among cluster data analysis, REML, MM, and EB. Although a variety of exchange rate volatility measures have been used in previous studies on the focal issue, there is still no consensus on which measure is the most appropriate to reach a one-sided conclusion in terms of the relationship between exchange rate volatility and international trade. The standard deviation and the moving average deviation applied in several studies (Chowdhury 1993; Dell’ Ariccia 1999) may ignore the information on stochastic processes through which exchange rates are generated. Indeed, the use of several GARCH extensions (linear vs. nonlinear, symmetrical vs. asymmetrical, with power effect, with level shift, etc.) may lead to different exchange rate volatility effects. GARCH models may be more useful because data from financial markets often exhibit volatility clustering where time series show periods of low and high volatility (tranquil and turbulent periods, respectively) instead of periods of constant volatility (Bouoiyour and Selmi 2014 c).

The fact that the majority of studies have excluded models that account for asymmetry and nonlinearity may also be a main contributor to the conflicting outcomes previously obtained. Consistently, our results revealed that nonlinearity (NL) and asymmetry (AS) are likely to prompt a significantly adverse exchange rate effect on international trade. Not surprisingly, it's not possible for exports to respond to every change in the exchange rate and thus there may be a band of inaction where exporters do not react to excessive exchange rate fluctuations. Further, exporters could react differently to appreciations and depreciations.

\footnotetext{
${ }^{6}$ Among these measures, six have statistically significant and positive coefficient estimates and three have negative estimated coefficients. They mention that the most used alternative measure is the conditional variance determined through ARCH or GARCH models. The last techniques make the estimation of a significantly positive exchange rate volatility effect on trade more likely.
} 
Given these considerations, it seems reasonable to assess whether there exists a nonlinear/ asymmetrical linkage between exchange rate volatility and trade.

Similar results are obtained from the meta-analysis regression of the whole sample with dummies for publication in academic journals and from the publication years (i.e., to test whether the earliest and the latest year of the sample period explains the statistically significant effect of exchange rate uncertainty on trade flows observed in the existing literature, Table 5).

The most interesting result is that, despite the inclusion of dummies for academic journal publication and publication year, the estimates reported in Table 5 suggest that the impact of exchange rate volatility on trade is likely to be adverse when it is measured in real rather than nominal terms, when "naïve” models are used as volatility measurements instead of GARCH models and when developing rather than developed economies are investigated. We also note that the conflicting relationship between the focal time series may be conditional upon potential moderator variables, such as a country's oil dependency, the degree of financial development (i.e., well developed or inefficient financial system), the adopted exchange rate regime, and the followed trade measures. Besides, we notice that the empirical studies on the focal issue exhibit substantial publication selection and show a significant genuine exchange rate volatility effect on trade flows after correction of publication bias.

The above findings reinforce, to an extent, the conclusions of Ćorić and Pugh (2010) and Haile and Pugh (2011), that the effect of exchange rate uncertainty on international trade varies substantially depending on country samples (developing or developed countries), the range of volatility measurements, the trade categories (total, sectoral or bilateral exports), and whether the exchange rate is measured in nominal or in real terms. Our research contributes to the previously mentioned MRA studies by adding relevant moderator variables that will allow for new paths to be found. We also provide insightful evidence supporting the argument that 
differences across studies can be attributed to the chosen exchange rate policy, trade reforms, and additional characteristics of the studied countries, such as oil dependency, the efficiency of their financial system, whether their economy adopts anti-cyclical price policy or countercyclical policy, whether the country is a price taker or price maker, and whether the study being performed considers asymmetry and nonlinearity when assessing this "complex" linkage.

While this replication is reported for convenience (and to check that we get the same results of Ćorić and Pugh (2010) and Haile and Pugh (2011)), the new estimates check the robustness of these results to different estimators and contribute to them by indicating that there are other potential elements of explanation for the pronounced heterogeneity in the empirical literature on the exchange rate volatility-trade relationship. Notably, the models Fstatistics (Tables 4 and 5) indicate that the estimated meta-regression analysis coefficients are jointly significant, though they seem rather weak. Accordingly, the model has partly captured the main sources of heterogeneity. Hence, further investigation to divide the sample into the total exports and sectoral exports studies in order to account for the dependent variable heterogeneity in the analyzed meta-regression analysis sample has been pursued. From these estimations, we can see whether or not these sub-sample findings are robust to a full MRA specification already reported (Tables 4 and 5). We cannot consider the bilateral exports as sub-sample since the most study characteristics are not reported in this sub-sample (e.g. CROSS, Panel, GTA, NL, AS) and those moderator variables cannot be therefore estimated in this last sample (i.e., bilateral exports literature). Only the MRA results with cluster-robust standard errors are summarized in Tables 6 and 7. It must be stressed here that the results do not change substantially among the rest of estimators REML, MM and $\mathrm{EB}^{7}$.

\footnotetext{
${ }^{7}$ For reasons of space, these results are not reported; they are available upon request.
} 
By partitioning the sample into studies of, respectively, total exports and sectoral exports literature, our multivariate MRA model ${ }^{8}$ reveals that: (1) the total exports literature appears influenced by positive publication bias, while no authentic empirical effect was revealed; (2) In comparison to the total exports literature, no evidence of publication bias was found for sectoral exports literature, even though a positive empirical effect was shown.

Both total exports and sectoral exports report different real exchange rate volatility effects on trade among developing countries(DC) and developed countries (DC*), between price makers (PM) and price takers (PT), between countries that adopt pegged exchange regime (PEG) and those adopting floating exchange regime (FER) and between oil and nonoil dependent economies (OD). The adverse effect of exchange rate variability is also conditional on whether a country pursues anti-cyclical policy (ACP) and whether they have a well developed financial system (DFS). These conclusions were discovered by comparing our sub-sample results. TEXP and SEXP studies focused on developing countries, price takers, and countries with inefficient financial system (IFS), together with counter-cyclical policy (CCP), tend to report a statistically significant and negative impact of exchange rate volatility on trade. If we compare these sub-sample results with the full sample (Table 4), the findings appear fairly solid and unambiguous. However, we see that the moderator variables characterizing the trade policy (GTA and RTA) followed are now statistically insignificant for sectoral exports researches (significant with positive coefficient for regional agreement and negative effect for global agreement; this seems valid for the other strands of the literature, i.e., the full sample (Tables 4 and 5) and total exports literature (Table 6). This suggests that sectoral exports studies are less conditional to trade reforms. Also, for the total exports subsample, the moderator variables capturing asymmetry (AS) and nonlinearity (NL) are highly

\footnotetext{
${ }^{8}$ It must be pointed out that, in the context of multivariate MRA, the constant and the precision measures are considered together with the estimated effects of $\mathrm{K}$ and $\mathrm{Z}$ moderator variables under consideration (Table 2).
} 
significant and negative; but the sectoral exports works considering NL display an insignificant exchange rate volatility coefficient. Accurately, we note the consistency of TEXP results and the inconsistency of SEXP findings with those of the full sample with respect to the estimated coefficient on the exchange rate volatility effect on trade.

Remarkably, a sharp difference between the total exports and the sectoral exports empirical literature is that studies that perform "naïve" models (NM) typically report less negative exchange rate volatility effect on trade, but the central relationship seems likely to be negative when focusing on the influence of exchange rate uncertainty on sectoral exports. However, the coefficients measuring the effect of GARCH models (GM) appear statistically report more negative (or less positive) trade effects for the two subsamples, consistently with the full sample estimates. This highlights how useful "sophisticated" techniques or the different GARCH extensions are (considering linearity, nonlinearity, symmetry, asymmetry, long memory process, transitory component, and permanent component) ${ }^{9}$ as measures of volatility in order to properly capture the reactions of exports to excessive exchange rate fluctuations.

Despite the incorporation of dummies for academic journal publication and publication year in sub-samples equations (Table 7), the previous results remain supported. A positive publication bias and no authentic empirical effect were found for the total exports literature. On the contrary, no publication bias was shown for the sectoral exports researches, while a positive authentic empirical effect was supported. Moreover, SEXP studies still more heterogeneous than TEXP empirical works and the exchange rate volatility effects on trade in these studies seem more conditional. The publication year has no effect on exchange rate volatility's coefficient neither for total exports studies nor for sectoral exports works, implying the inexistence of structural change. However, a published paper in an academic

\footnotetext{
${ }^{9}$ For more details about different GARCH extensions and their effectiveness in determining exchange rate volatility, you can refer to Bouoiyour and Selmi (2014 a, b).
} 
journal (AJ) displays a statistically negative and significant coefficient, which appears stronger for SEXP studies. This suggests that SEXP literature appears more sensitive on whether the paper is published in AJ than TEXP literature.

\section{Conclusion}

The debate concerning the effects of exchange rate volatility on international trade is not recent. This study applied meta-regression analysis to the extant empirical literature on the effects of exchange rate volatility on international trade. In particular, we conducted metaregression analysis on 41 studies published from 1978 to 2014 with 807 estimates, correcting for publication bias. This meta-regression builds on a previous MRA by Ćorić and Pugh (2010) and Haile and Pugh (2011) by enlarging the data set and by extending the database with variables capturing "financial development", "exchange policy", monetary policy", “trade policy” and “oil dependency”.

Our main findings reveal that the empirical studies exert a substantial publication selection, which is not consistent with Haile and Pugh's (2011) study, according to which there is evidence of only modest publication bias. The most important contribution of this MRA is to have identified a range of research characteristics that help to explain the pronounced heterogeneity of the estimates reported in the literature. Although there is still a large variation in the estimated effect size that is not explained by the meta-regression models, our findings reveal the role played by model specifications, samples, datasets, time horizons and distinct countries characteristics (the degree of oil dependency, the efficiency of financial systems, the appropriateness of anti-cyclical or countercyclical price policy, or if the country is a price taker or price maker). We found that authors' choices of modeling strategies significantly impact the estimated effect of exchange rate variability on trade. In particular, studies that employ CROSS, PANEL, and OLS are more likely to display an adverse 
exchange rate volatility effect. Besides, contrary to Haile and Pugh’s (2011) findings and consistent with Ćorić and Pugh's (2010) outcomes, this paper supports the idea that alternative proxies exchange rate volatility (sophisticated models) may more considerably affect the estimated exchange rate volatility effects on trade compared to the "naïve" models or standard measures. More interestingly, our assessment of the heterogeneity shows the conditions in which an adverse exchange rate volatility effect of trade is most likely to be identified; namely, when studies empirically gauge the effect of low-frequency exchange rate volatility on trade between developing economies (DC), price takers (PT), oil dependent countries (OD), economies with less developed financial systems and counter-cyclical policy. This finding is consistent with the suggestion that that hedging in the currency market, the efficiency of financial system and the adoption of anti-cyclical price policy may significantly mitigate the adverse trade effect of exchange rate volatility. The development of forward markets coupled with efficient financial system and efficacious fiscal policy in developing countries may promote trade performance in these countries. Furthermore, our findings indicate that there may be a regime effect, whereby exchange rate variability under fixed exchange regime exerts a different effect on international trade than exchange rate volatility does under floating exchange regime. These results are, to some extent, in accordance with the findings and policy implications suggested by Ćorić and Pugh (2010) and Haile and Pugh (2011). More tentatively, our MRA findings show also that while an adverse effect of exchange rate variability on trade is discovered under global trade agreement (GTA), a positive effect is well shown under regional trade agreement (RTA).

Furthermore, we address the heterogeneity of the dependent variable by partitioning the sample into studies of, respectively, total exports and sectoral exports. The most interesting results are: (1) the total exports literature is affected by positive publication bias, but we do not identify an authentic empirical effect; (2) the sectoral exports studies are not 
affected by publication bias, while there is evidence of a positive authentic empirical effect. This suggests that authentic empirical effect in the sectoral exports literature is conditional on study characteristics like specification, sample and volatility proxies. In comparison with SEXP literature, the TEXP literature is more homogenous and its identified exchange rate volatility effect seems less conditional. All the obtained findings (full sample and sub-samples investigations) appear robust among the different estimators and to the inclusion of dummies for the type of research outlet and publication year.

The present research provides evidence for policy makers that the average trade effects of exchange rate uncertainty suggested by this literature are not sufficiently robust to generalize across countries, exchange rate regimes, trade and monetary policy encompassing the degree of financial development and the oil dependency. Our most important advice for policy makers is that economic research does not show a "one-sided" representative effect size. In a nutshell, the influence of exchange rate volatility on trade differs substantially depending on both objective context and the subjective choice of the empirical strategy generally and the volatility proxy used particularly.

Before ending, we should mention that the extension of Ćorić and Pugh (2010) and Haile and Pugh (2011) provides a strong robustness check on their results with respect to different samples and further potential moderator variables as well as better paths into why the empirical literature on the relationship between exchange rate volatility and trade is so heterogeneous in its findings by identifying additional sources. 


\section{References}

Abbott, A., Darnell, A., and Evans, L. 2001. The influence of exchange ratevariability on UK exports. Applied Economic Letters 8: 47-49.

Achy, L. and Sekkat, K. 2001. The European single currency and MENA’s exports to Europe. Review of Development Economics 7: 563- 582.

Adam, A., Kammas, P. and Lagou, A., 2013. The effect of globalization on capital taxation: What have we learned after 20 years of empirical studies? Journal of Macroeconomics 35: 199-209.

Alatalo, R. V., Mappes, J. and Elgar, M. 1997. Heritabilities and paradigm shifts. Nature 385 : $402-403$.

Aristotelous, K. 2001. Exchange-rate volatility, exchange-rate regime, and trade volume: evidence from the UK-US export function (1989-1999).Economic Letters 72: 87-89.

Arize, A. C.1996. Real exchange rate volatility and trade flows: the experience of eight European economies.International Review of Economics and Finance 5:187-205.

Arize, C. A.,Osang, T., and Slottje J. D. 2000. Exchange rate volatility and foreign trade: evidence from Thirteen LDC.s.Journal of Business and Economic Statistics 18 (1): 1017.

Bahmani-Oskooee, M. and Payesteh, S.1993. Does exchange rate volatility deter trade volume of LDC’s? Journal of Economic Development 18: 189-205.

Benos, N. and Zotou, S. 2014. Education and Economic Growth: A Meta-Regression Analysis. World Development, 64(C): 669-689.

Bom, P. R. D., and Ligthart J. E. 2008. How Productive is Public Capital? A Meta-Analysis. CESifo Working Paper No. 2206.

Bouoiyour, J. and Selmi, R. 2014 a. Exchange Volatility and Export Performance in Egypt: New Insights from Wavelet Decomposition and Optimal GARCH Model. The Journal 
of International Trade \& Economic Development: An International and Comparative Review, DOI: 10.1080/09638199.2014.889740

Bouoiyour, J. and Selmi, R. 2014 b. Exchange volatility and trade performance in Morocco and Tunisia: what have we learned so far? Macroeconomics and Finance in Emerging Market Economies, DOI:10.1080/17520843.2014.880150

Bouoiyour, J. and Selmi, R. 2014 c. How Robust is the Connection between Exchange Rate Uncertainty and Tunisia’s Exports? Working paper CATT, University of Pau.

Bouoiyour, J. and Selmi, R. 2014 d. Exchange Rate Impact on Russia’s Exports: Some Evidence from an Evolutionary Co-spectral Analysis. Working paper CATT, University of Pau.

Bouoiyour, J., Selmi, R. and Ozturk, I. 2014. The Nexus between Electricity Consumption and Economic Growth: New Insights from Meta-Analysis. International Journal of Energy Economics and Policy 4(4): 621-635.

Bredin, D., Fountas, S.,and Murphy, E. 2003. An Empirical Analysis of Short Run and Long Run Irish Export Functions: Does Exchange Rate Volatility Matter? International Review of Applied Economics 17: 193-208.

Cheong, C., Mehari, T., Pattichis, C. and Williams, L.V. 2002. Exchange Rate Volatility and UK Exports: Implications for EMU membership. Discussion paper, Nottingham Trent University.

Chit, M.C. and Judge, M. 2011. Nonlinear effect of exchange rate volatility on exports: the role of financial sector development in emerging East Asian economies. International Review of Applied Economics 25 (1): 107-119.

Chowdhury, A. 1993. Does Exchange Rate Volatility Depress Trade Flows? Evidence from Error Correction Models. The Review of Economics and Statistics 75: 700-706. 
Clark, P., Tamirisa, N., Wei, S.-J., Sadikov, A. and Zeng, L. 2004. Exchange rate volatility and trade flows: some new evidence. International Monetary Fund, Occasional Paper 235.

Ćorić, B. and Pugh, G. 2010. The effects of exchange rate variability on international trade: a meta-regression analysis. Applied Economics 42: 2631-2644.

Dell'Ariccia, G. 1999. Exchange Rate Fluctuations and Trade Flows: Evidence from the European Union. IMF Staff Papers 46(3): 315-334.

Dohring, B., 2008. Hedging and invoicing strategies to reduce exchange rate exposure: a euro-area perspective, Economic Papers 299, European Commission.

Doucouliagos, C. 2005. Publication Bias in the Economic Freedom and Economic Growth Literature. Journal of Economic Surveys 19(3): 367-387.

Doucouliagos, H., and Laroche, P. 2009. Unions and profits: A meta regression analysis. Industrial Relations: A Journal of Economy and Society 48 (1): 146-84.

Doucouliagos, C., and Stanley, T. D. 2009. Publication Selection Bias in Minimum-Wage Research? A Meta-Regression Analysis. British Journal of Industrial Relations 47(2): 406-428.

Effendic, A., Pugh, G., and Adnett, N. 2011. Institutions and Economic Performance: a Meta Regression Analysis. European Journal of Political Economy 27(3): 586-599.

Égert, B. and Morales-Zumaquero, A. 2007. Exchange Rate Regimes, Foreign Exchange Volatility and Export Performance in Central and Eastern Europe: Just Another Blur Project? William Davidson Institute Working Papers Series wp782, University of Michigan.

Fountas, S. and Aristotelous, K. 2003. Does the exchange rate regime affect export volume? Evidence from bilateral exports in US-UK trade: 1900-98, The Manchester School 71: 51-64. 
Franke, G. 1991. Exchange rate volatility and international trading strategy.” Journal of International Money and Finance 10 (2): 292-307.

Frankel, J. and Rose, A. 2002. An Estimate of The Effect Of Common Currencies On Trade And Income. The Quarterly Journal of Economics, MIT Press 117(2): 437-466.

Gervais, J-P., Larue, B. and Bonroy, O. 2004. Investigating Non-Linearities in the Relationship Between Real Exchange Rate Volatility and Agricultural Trade. International Trade 0407004, EconWPA.

Gontard-Danek, M. C. and Moller, A. P. 1999. The strength of sexual selection: a meta analysis of bird studies. Behavioral ecology 10: 476 - 486.

Haile G.M. and Pugh, G. 2011. Does exchange rate volatility discourage international trade? A meta-regression analysis. The Journal of International Trade and Economic Development, DOI:10.1080/09638199.2011.565421

Harmon, C., Oosterbeek, H., and Walker, I. 2003. The returns to education: Microeconomics. Journal of Economic Surveys 17(2): 115-155.

Hooper, P., and Kohlhagen, S. W., 1978. The Effect of Exchange Rate Uncertainty on Prices and Volume of International Trade. Journal of International Economics 8: 483-511.

Jarrell, S.B, and Stanley, T. D. 1990. A meta-analysis of the union-nonunion wage gap. Industrial and Labor Relations Review 44(1): 54-67.

Kandilov, I. 2005. The Effects of Exchange Rate Volatility on Agricultural Trade. Working paper, Agricultural and Resource Economics NC State.

Kumar, R. and Dhawan, R. 1991. Exchange Rate Volatility and Pakistani’s Exports to the Developed World, 1974-85. World Development 19: 1225-1240.

Lee, J. 1999. The effect of exchange rate volatility on trade in durables. Review of International Economics 7: 189-201. 
Lee,K.S., and Saucier, P. 2005. Exchange Rate Instability and Trade Integration: The Case of Asia. 5th International Conference of International Trade and Logistics Corporate Strategies and the Global Economy.Conference Paper (Le Havre), 28-29 September.

Mavridis, D., and Salanti, G. 2012. A practical introduction to multivariate meta-analysis. Statistical Methods in Medical Research, 21 (1): 1-26.

McKenzie, M. D. and Brooks, R. D. 1997. The impact of exchange rate volatility on German - US trade flows. Journal of International Financial Markets, Institutions and Money 7: 73-87.

McKenzie, D.1998. The Impact of Exchange Rate Volatility on Australian Trade Flows. Journal of International Financial Markets.” Institutions and Money 8: 21-38.

Olimov, U. and Nishanbay, S. 2008. The Effects of the Real Exchange Rate Volatility and Misalignments on Foreign Trade Flows in Uzbekistan. Working paper MPRA N॰9749.

Pozo, S. 1992.Conditional exchange rate volatility and the volume of international trade: evidence from the early 1990’s. Review of Economics and Statistics 74: 325-329.

Pugh, G., Coric, B. and Haile, M-G.2012. An introduction to meta-regression analysis (MRA): Using the example of trade effects of exchange rate variability. Chapter 20 of the edited Book: Macroeconomics and Beyond in Honour of WimMeeusen.

Poulin, R. 2000. Manipulation of host behaviour by parasites: a weakening paradigm? Proceedings of the Royal Society of London 267: 787 - 792.

Rey S. 2006. Effective exchange rate volatility and MENA countrieseexports to the EU. Journal of Economic Development 31: 1-32.

Sadikov A., Zeng L., Clark P., Wei S-P. etTamirisa N.2004. A New Look at Exchange Rate Volatility and Trade Flows. IMF Occasional Papers N² 235. 
Sauer, C. and Bohara, A. K.2001. Exchange rate volatility and exports: regional differences between developing and industrialized countries. Review of International Economics 9: 133-152.

Simmons, L. W., Tomkins, J. L., Kotiaho, J. S. and Hunt, J. 1999. Fluctuating paradigm. Proceedings of the Royal Society of London, 266: 593-595.

Stanley, T. D. 2001. Wheat from chaff: Meta - analysis as quantitative literature review. Journal of Economic Perspectives 15: 131-150.

Stanley, T. 2005. Beyond publication bias. Journal of Economic Survey 19(3): 309-345.

Stanley, T. D. 2008. Meta-Regression Methods for Detecting and Estimating Empirical Effects in the Presence of Publication Selection. Oxford Bulletin of Economics and Statistics 70 (1): 103-127.

Stanley, T.D. and Doucouliagos, C. 2012. Meta-regression Analysis in Economics and Business. Routledge Advances in Research Methods.

Stokman, A. 1995. Effect of exchange rate risk on intra-EC trade,” De Economist 143: 41-54.

Thompson, S. G., and Sharp, S. J. 1999. Explaining heterogeneity in meta-analysis: A comparison of methods. Statistics in Medicine 18: 2693-2708.

Véganzonès-Varoudakis, M. A. and Nabli, M.K. 2002. Exchange Rate Regime and Competitiveness of Manufactured Exports: The case of MENA Countries. CERDI Working paper $\mathrm{N}^{\circ} 200230$.

Vergil, H. 2001. Exchange rate volatility in Turkey and its effects on trade flows. Journal of Economic and Social Research 4 (1): 83-99.

Verheyen, F. 2013. Exchange rate nonlinearities in EMU exports to the US. Economic Modelling 32(C): 66-76. 
Table 1. Descriptive statistics

\begin{tabular}{|c|c|c|c|c|c|c|}
\hline Studies & $\mathrm{N}^{\circ}$ of coefficients & Mean & Median & Maximum & Minimum & Std. Dev. \\
\hline $\begin{array}{l}\text { Hooper and Kohlhagen } \\
\text { (1978) }\end{array}$ & 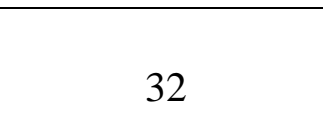 & 5.346250 & 0.360000 & 82.76000 & -41.30000 & 31.99952 \\
\hline Franke (1991) & 3 & 0.516500 & 0.516500 & 0.606000 & 0.427000 & 0.126572 \\
\hline $\begin{array}{l}\text { Kumar and } \\
\text { Dhawan(1991) }\end{array}$ & 12 & -0.022500 & -0.027500 & 0.071000 & -0.089000 & 0.062372 \\
\hline Pozo (1992) & 2 & -0.108050 & -0.108050 & -0.094800 & -0.121300 & 0.018738 \\
\hline Chowdhury (1993) & 6 & -0.143200 & -0.126600 & -0.097500 & -0.227400 & 0.051462 \\
\hline Stockman (1995) & 6 & 1.901000 & 0.475500 & 6.981000 & 0.002000 & 2.763013 \\
\hline $\begin{array}{l}\text { McKenzie and Brooks } \\
\text { (1997) }\end{array}$ & 8 & 608.2750 & 659.6500 & 836.2000 & 277.6000 & 243.3517 \\
\hline McKenzie (1998) & 11 & 153.5583 & 133.4000 & 435.8000 & 29.32000 & 147.8287 \\
\hline Arize (1997) & 13 & -0.118000 & -0.156000 & 0.089000 & -0.273000 & 0.140862 \\
\hline Arize (1998) & 9 & -0.378333 & -0.460500 & 0.183000 & -0.869000 & 0.427761 \\
\hline Aize et al. (2000) & 55 & -0.212833 & -0.242500 & -0.063000 & -0.373000 & 0.118016 \\
\hline Dell'Arricia (1999) & 6 & -0.129000 & -0.099000 & 0.093000 & -0.411000 & 0.253815 \\
\hline Bredin et al. (1998) & 12 & 0.017600 & -0.011000 & 0.273000 & -0.153000 & 0.156057 \\
\hline Lee (1999) & 3 & -0.126000 & -0.467000 & 0.621000 & -0.532000 & 0.647737 \\
\hline $\begin{array}{l}\text { Frankel and Rose } \\
(2000)\end{array}$ & 8 & -0.145000 & -0.098500 & 0.073000 & -0.456000 & 0.223838 \\
\hline Abott et al. (2001) & 2 & 0.020000 & 0.020000 & 0.100000 & -0.060000 & 0.113137 \\
\hline $\begin{array}{l}\text { Achy and Sekkat } \\
(2001)\end{array}$ & 6 & -0.001400 & -0.036000 & 0.121000 & -0.042000 & 0.069522 \\
\hline Aristotelous (2001) & 6 & -0.153250 & -0.196000 & 0.226000 & -0.447000 & 0.298360 \\
\hline Doyle (2001) & 6 & -0.005333 & -0.006500 & 0.089000 & -0.092000 & 0.058168 \\
\hline $\begin{array}{l}\text { Sauer and Botara } \\
(2001)\end{array}$ & 3 & -0.001400 & -0.036000 & 0.121000 & -0.042000 & 0.069522 \\
\hline Vergil (2001) & 4 & -0.050000 & -0.040000 & 0.010000 & -0.130000 & 0.060553 \\
\hline Cheong et al. (2002) & 4 & 0.003400 & 0.003100 & 0.004600 & 0.002800 & 0.000816 \\
\hline $\begin{array}{l}\text { Véganzonès and Nabli } \\
\text { (2002) }\end{array}$ & 2 & -0.185000 & -0.185000 & -0.100000 & -0.270000 & 0.120208 \\
\hline $\begin{array}{l}\text { Fountas and } \\
\text { Aristotelous (2003) }\end{array}$ & 3 & -0.150667 & -0.148000 & -0.065000 & -0.239000 & 0.087031 \\
\hline $\begin{array}{l}\text { Yuan and Awokus } \\
\text { (2003) }\end{array}$ & 6 & -0.068167 & -0.020000 & 0.007000 & -0.355000 & 0.141350 \\
\hline Baum et al. (2004) & 14 & -0.140714 & 0.231000 & 6.264000 & -6.104000 & 3.257404 \\
\hline Clarck et al. (2004) & 36 & -0.093800 & -0.111000 & 0.091000 & -0.224000 & 0.115329 \\
\hline Gervais et al. (2004) & 5 & -0.316000 & -0.330000 & 0.610000 & -0.940000 & 0.631015 \\
\hline Sadikov et al. (2004) & 3 & -0.579667 & -0.519000 & -0.484000 & -0.736000 & 0.136515 \\
\hline Honroyiannis et al. & 6 & -0.039333 & 0.015500 & 0.149000 & -0.316000 & 0.194519 \\
\hline
\end{tabular}




\begin{tabular}{|l|c|c|c|c|c|c|}
\hline$(2005)$ & & & & & & \\
\hline Kandilov (2005) & 228 & -2.265000 & -0.945000 & -0.150000 & -8.930000 & 3.347696 \\
\hline Lee and Saucier (2005) & 8 & -0.710667 & -0.700500 & 0.611000 & -1.817000 & 0.790533 \\
\hline Rey (2006) & 24 & -0.619167 & -0.760000 & 0.506000 & -1.405000 & 0.795990 \\
\hline $\begin{array}{l}\text { Egert and Zumaquero } \\
(2007)\end{array}$ & 100 & -0.105833 & -0.079000 & 0.006000 & -0.346000 & 0.124035 \\
\hline $\begin{array}{l}\text { Olimov and Nishanbay } \\
(2008)\end{array}$ & 3 & 1.416667 & 1.180000 & 2.000000 & 1.070000 & 0.508167 \\
\hline $\begin{array}{l}\text { Hosseini and Moghadsi } \\
(2010)\end{array}$ & 6 & -0.013550 & -0.011600 & 0.078000 & -0.109000 & 0.078573 \\
\hline Chit and Judge (2011) & 12 & -2.080167 & -0.687000 & -0.302000 & -5.256000 & 2.457727 \\
\hline $\begin{array}{l}\text { Bouoiyour and Selmi } \\
(2014 \text { a) }\end{array}$ & 16 & -0.021000 & -0.076000 & 0.183000 & -0.121000 & 0.123432 \\
\hline $\begin{array}{l}\text { Bouoiyour and Selmi } \\
(2014 \text { b) }\end{array}$ & 98 & -0.086333 & -0.131500 & 0.201000 & -0.281000 & 0.187422 \\
\hline $\begin{array}{l}\text { Bouoiyour and Selmi } \\
(2014 \text { c) }\end{array}$ & 14 & -0.049400 & -0.054000 & 0.228000 & -0.314000 & 0.192374 \\
\hline $\begin{array}{l}\text { Bouoiyour and Selmi } \\
(2014 d)\end{array}$ & 6 & 0.004250 & 0.002500 & 0.011000 & 0.001000 & 0.004573 \\
\hline Total & 810 & 16.68535 & -0.069000 & 836.2000 & -41.30000 & 96.16141 \\
\hline
\end{tabular}

Figure 1. Funnel plot graph

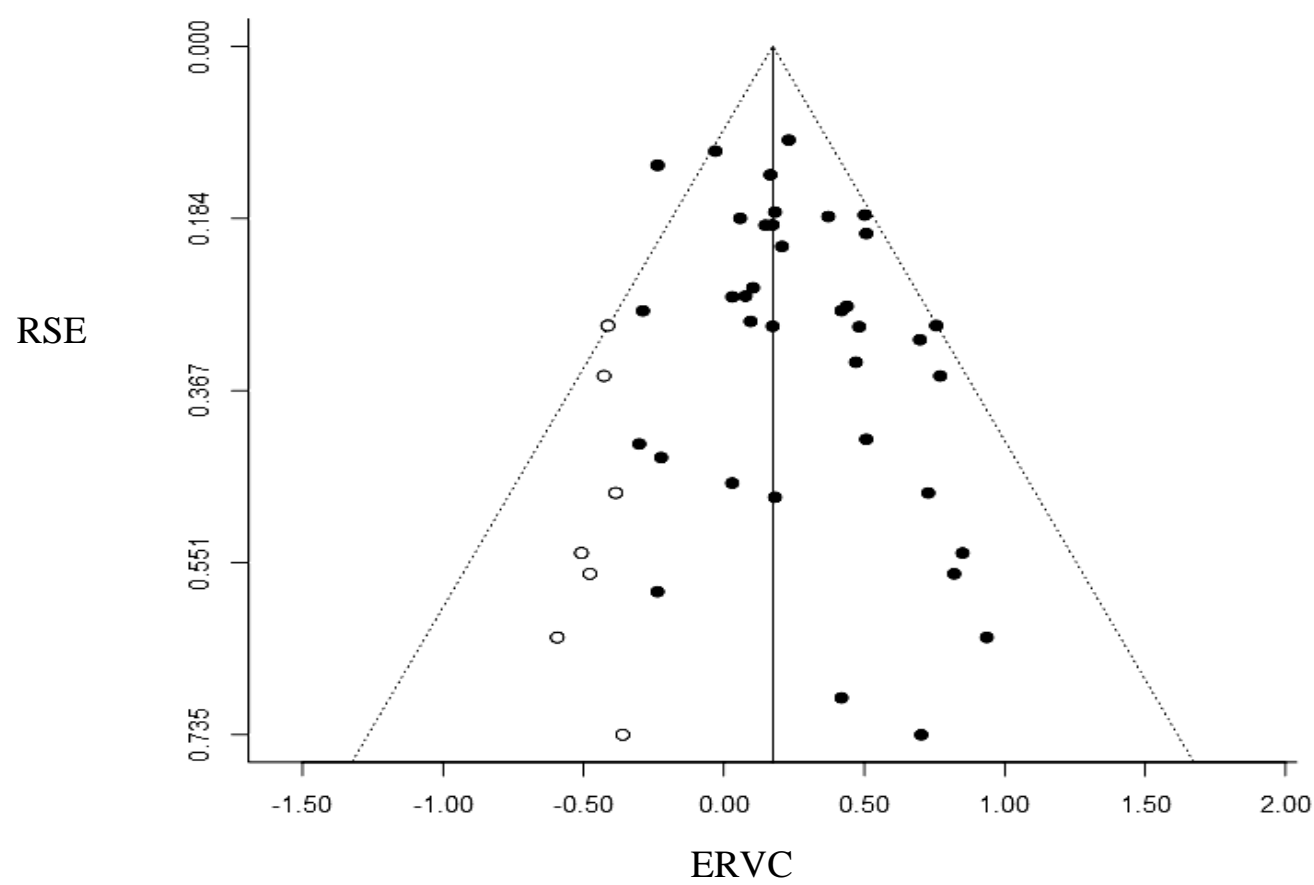

Notes: The variables ERVC and RSE represent, respectively, the exchange rate volatility coefficient and the inverse of the standard error. 
Table 2. $\mathrm{K}$ and $\mathrm{Z}$ variables for Meta-regression analysis

\begin{tabular}{|c|c|}
\hline & Description of the variables \\
\hline & Variables $^{\mathrm{a}}$ \\
\hline t-statistic & The t-statistic of the coefficient of interest of the study. \\
\hline & K-variables ${ }^{\mathrm{b}}$ \\
\hline Sample size (SZ) & The sample size used in this study. \\
\hline & Z-variables ${ }^{\mathrm{C}}$ \\
\hline Antse (1/se) & $=1 /$ the standard error of the coefficient of interest of the study \\
\hline Total exports (TEXP) & $=1$, if the study considers total exports as dependent variable. \\
\hline Sectoral exports (SEXP) & $=1$, if the study considers sectoral exports as dependent variable. \\
\hline Bilateral exports (BEXP) & $=1$, if the study considers bilateral exports as dependent variable. \\
\hline Low frequency (LF) & =1, if study considers low frequency exchange rate variability. \\
\hline High frequency (HF) & =1, if study considers high frequency exchange rate variability. \\
\hline Naïve models (NM) & $=1$, if the study uses "naïve models" as measure of volatility. \\
\hline GARCH models (GM) & $=1$, if the study uses GARCH models as proxies of volatility. \\
\hline Cross-sectional data (CROSS) & $=1$, if estimate relates to cross-sectional data. \\
\hline Panel (PANEL) & $=1$, if the study employs panel data. \\
\hline OLS method (OLS) & $\begin{array}{l}=1 \text {, if the study uses OLS method for the estimation of the link between } \\
\text { exchange rate volatility and exports. }\end{array}$ \\
\hline Developed countries (DC*) & $=1$, if the study focuses on the case of developed countries. \\
\hline Developing countries (DC) & $=1$, if the study focuses on the case of developing countries. \\
\hline Nominal terms (NT) & $\begin{array}{l}=1 \text {, if the relationship between exports and exchange rate volatility has been } \\
\text { investigated in nominal terms. }\end{array}$ \\
\hline Real terms (RT) & $\begin{array}{l}=1 \text {, if the relationship between exports and exchange rate volatility has been } \\
\text { investigated in real terms. }\end{array}$ \\
\hline Pegged exchange regime (PEXCH) & $=1$, if the study focuses on the countries that adopt pegged exchange regime. \\
\hline Floating exchange regime (FEXCH) & $=1$, if the study focuses on the countries that adopt floating exchange regime. \\
\hline Global trade agreement (GTA) & $=1$, if the countries under consideration have signed a global trade agreement. \\
\hline Regional trade agreement (RTA) & $=1$, if the countries under consideration have signed a regional trade agreement. \\
\hline Developed financial system (DFS) & $=1$, if the studied countries are characterized by developed financial system. \\
\hline Inefficient financial system (IFS) & $=1$, if the studied countries are characterized by inefficient financial system. \\
\hline Anti-cyclical policy (ACP) & $=1$, if the concerned countries adopt an anti-cyclical price policy. \\
\hline Countercyclical policy (CCP) & $=1$, if the concerned countries adopt countercyclical price policy. \\
\hline Price maker (PM) & $=1$, if the studied economies are price makers. \\
\hline Price taker $(\mathrm{PT})$ & $=1$, if the studied economies are price takers. \\
\hline Oil dependency (OD) & $=1$, if the studied countries are highly dependent to oil sector. \\
\hline Asymmetry (AS) & $=1$, if the study accounts for asymmetry. \\
\hline Nonlinearity (NL) & $=1$, if the study accounts for nonlinearity. \\
\hline Academic journal (AJ) & $=1$, if the study has been published by an academic journal. \\
\hline Publication year (PUBY) & The year the study was published. \\
\hline
\end{tabular}

Notes: ${ }^{a}$ All variables are included in a general-to-specific modeling approach; ${ }^{b} \mathrm{~K}$ variables may affect the likelihood of being selected for publication; ${ }^{\mathrm{c}} \mathrm{Z}$ variables may affect the magnitude of the exchange rate volatility coefficient. 
Table 3. Funnel Asymmetry and precision-effect tests (FAT-PET)

\begin{tabular}{|l|c|c|c|c|}
\hline Variables & Cluster $^{\mathrm{a}}$ & REML $^{\mathrm{b}}$ & $\mathrm{MM}^{\mathrm{C}}$ & $\mathrm{EB}^{\mathrm{d}}$ \\
\hline Antse$=(1 / \mathrm{se})$ & $0.0179^{*}$ & $0.0176^{* *}$ & 0.0362 & $0.0254^{* * *}$ \\
& $(1.6982)$ & $(3.0126)$ & $(1.6048)$ & $(3.4951)$ \\
Intercept & $1.3824^{* * *}$ & $1.3895^{* * *}$ & $1.3512^{* * *}$ & $1.4118^{* * *}$ \\
& $(4.7613)$ & $(3.8640)$ & $(4.2067)$ & $(3.9254)$ \\
\hline R-squared & 0.1638 & 0.1495 & 0.1430 & 0.1846 \\
\hline Ramsey Reset test & $\mathrm{F}(3,612)=4.79$ & \\
& Prob $>\mathrm{F}=0.0932^{\mathrm{e}}$ & & \\
\hline
\end{tabular}

Notes: *, **, *** denote statistical significance at 10\%, 5\% and 1\% levels respectively; t-values are reported in parentheses (dependent variable: t-statistic); ${ }^{\text {a }}$ Cluster data analysis presents the FAT results with cluster-robust standard errors; ${ }^{\mathrm{b}}$ REML presents the FAT-PET results with restricted maximum likelihood; ${ }^{\mathrm{c}}$ MM presents the FAT-PET results with the moment estimator; ${ }^{d}$ EB presents the FAT-PET results with the empirical Bayes iterative procedure; The Ramsey reset test rejects the null at all levels of statistical significance, indicating that there are no omitted non-linear terms, i.e., that there is a linear relationship in the data.

Table 4. Meta- regression analysis (considering working papers and publications in

\section{academic journals)}

\begin{tabular}{|c|c|c|c|c|}
\hline Moderator variables & Cluster $^{\mathrm{a}}$ & REML $^{b}$ & $\mathrm{MM}^{\mathrm{c}}$ & $\mathrm{EB}^{\mathrm{d}}$ \\
\hline $\mathrm{ANTSE}=1 / \mathrm{se}$ & $\begin{array}{l}1.5287 * * \\
(2.3456)\end{array}$ & $\begin{array}{l}1.1422 * \\
\text { (1.6988) }\end{array}$ & $\begin{array}{c}0.5682 \\
(1.0234)\end{array}$ & $\begin{array}{c}1.3679 * * * \\
(4.1355)\end{array}$ \\
\hline Intercept & $\begin{array}{c}1.3467 * * * \\
(5.1289)\end{array}$ & $\begin{array}{l}1.3652^{* *} \\
(2.8916)\end{array}$ & $\begin{array}{l}\text { 1.0159* } \\
\text { (1.6954) }\end{array}$ & $\begin{array}{c}1.3584^{* * *} \\
(3.6175)\end{array}$ \\
\hline SZ & $\begin{array}{c}-0.4513 \\
(-0.8660)\end{array}$ & $\begin{array}{c}-0.3256 \\
(-1.1431)\end{array}$ & $\begin{array}{c}0.6752 \\
(0.5419)\end{array}$ & $\begin{array}{c}-0.2894 \\
(-1.5137)\end{array}$ \\
\hline TEXP/se & $\begin{array}{l}-0.0147^{*} \\
(-1.8705)\end{array}$ & $\begin{array}{c}-0.0256 * * * \\
(3.8714)\end{array}$ & $\begin{array}{c}-0.0102 \\
(-0.6853)\end{array}$ & $\begin{array}{c}-0.0311^{* *} \\
(-2.7819)\end{array}$ \\
\hline SEXP/se & $\begin{array}{l}-0.1136^{*} \\
(-1.9124)\end{array}$ & $\begin{array}{l}0.0997 * \\
(1.8562)\end{array}$ & $\begin{array}{l}-0.1014^{*} \\
(-1.7325)\end{array}$ & $\begin{array}{c}-0.0986 * * * \\
(-5.0127)\end{array}$ \\
\hline $\mathrm{BEXP} / \mathrm{se}$ & $\begin{array}{c}0.0879 \\
(1.1348)\end{array}$ & $\begin{array}{c}0.0345 \\
(0.7651)\end{array}$ & $\begin{array}{c}0.0096 \\
(1.1512)\end{array}$ & $\begin{array}{l}0.0671 \\
(1.000)\end{array}$ \\
\hline NM/se & $\begin{array}{c}0.2715^{* * * *} \\
(3.8641)\end{array}$ & $\begin{array}{l}-0.1692^{* *} \\
(-2.1174)\end{array}$ & $\begin{array}{l}0.2019^{*} \\
(1.6933)\end{array}$ & $\begin{array}{c}-0.3147 * * * \\
(-4.1769) \\
\end{array}$ \\
\hline SM/se & $\begin{array}{c}-0.0489 * * * \\
(-5.1167)\end{array}$ & $\begin{array}{l}-0.0512^{* *} \\
(-2.7650)\end{array}$ & $\begin{array}{c}-0.0161 \\
(-1.3259)\end{array}$ & $\begin{array}{c}-0.0495 * * * \\
(-3.8924)\end{array}$ \\
\hline CROSS/se & $\begin{array}{l}-0.1230 * \\
(-1.7804)\end{array}$ & $\begin{array}{l}-0.1002^{* *} \\
(-2.4357)\end{array}$ & $\begin{array}{l}-0.0876^{*} \\
(-1.7924)\end{array}$ & $\begin{array}{c}-0.1376^{* * * *} \\
(-4.1098)\end{array}$ \\
\hline PANEL/se & $\begin{array}{c}0.0195 \\
(0.8724) \\
\end{array}$ & $\begin{array}{c}0.0086 \\
(1.1453) \\
\end{array}$ & $\begin{array}{c}-0.0213 \\
(-1.0007) \\
\end{array}$ & $\begin{array}{l}0.0201^{*} \\
(1.7624) \\
\end{array}$ \\
\hline OLS/se & $\begin{array}{c}0.0946 * * * \\
(3.8772)\end{array}$ & $\begin{array}{l}-0.0675^{* *} \\
(-2.9211)\end{array}$ & $\begin{array}{c}-0.0414 \\
(-1.2539)\end{array}$ & $\begin{array}{c}0.1013 * * * \\
(5.6197)\end{array}$ \\
\hline DC*/se & $\begin{array}{l}-0.2369 * \\
(-1.8122)\end{array}$ & $\begin{array}{l}-0.1946 * * \\
(-2.3857)\end{array}$ & $\begin{array}{l}-0.1856^{*} \\
(-1.7129)\end{array}$ & $\begin{array}{c}0.2380 * * * \\
(4.4569)\end{array}$ \\
\hline DC/se & $\begin{array}{l}-0.1055^{* *} \\
(-2.3493)\end{array}$ & $\begin{array}{l}0.0768 * \\
(1.8320) \\
\end{array}$ & $\begin{array}{c}-0.0616 \\
(-1.0117) \\
\end{array}$ & $\begin{array}{c}-0.0928 * * \\
(-2.8073)\end{array}$ \\
\hline NT/se & $\begin{array}{c}0.0026 \\
(1.4807)\end{array}$ & $\begin{array}{c}0.0194 \\
(1.1552)\end{array}$ & $\begin{array}{c}0.0102 \\
(0.7869)\end{array}$ & $\begin{array}{c}0.0063 \\
(1.0002)\end{array}$ \\
\hline $\mathrm{RT} / \mathrm{se}$ & $\begin{array}{l}-0.1725^{* *} \\
(-2.6149)\end{array}$ & $\begin{array}{c}-0.1023 * * * \\
(-5.6718)\end{array}$ & $\begin{array}{l}-0.0952^{*} \\
(-1.7487)\end{array}$ & $\begin{array}{c}0.2011^{* * *} \\
(4.3276)\end{array}$ \\
\hline LF/se & $-0.1027^{*}$ & $-0.1000 * *$ & 0.0675 & $-0.0876 * * *$ \\
\hline
\end{tabular}




\begin{tabular}{|c|c|c|c|c|}
\hline & $(-1.6928)$ & $(-2.4519)$ & $(1.4113)$ & $(-3.1542)$ \\
\hline $\mathrm{HF} / \mathrm{se}$ & $\begin{array}{c}0.0654 * * * \\
(4.4963)\end{array}$ & $\begin{array}{l}-0.0542^{*} \\
(-1.6988) \\
\end{array}$ & $\begin{array}{c}-0.0234 \\
(-1.0000) \\
\end{array}$ & $\begin{array}{l}0.0708 * * \\
(2.6415) \\
\end{array}$ \\
\hline $\mathrm{PER} / \mathrm{se}$ & $\begin{array}{l}-0.1013^{*} \\
(-1.9485)\end{array}$ & $\begin{array}{l}0.1237^{*} \\
(1.7814)\end{array}$ & $\begin{array}{l}0.1000^{*} \\
(1.7169)\end{array}$ & $\begin{array}{c}-0.1613^{* * * *} \\
(-3.9825)\end{array}$ \\
\hline FER/se & $\begin{array}{c}0.1604 * * * \\
(3.2875)\end{array}$ & $\begin{array}{l}0.0950^{*} \\
(1.7266)\end{array}$ & $\begin{array}{l}0.0868 * \\
(1.9153)\end{array}$ & $\begin{array}{l}0.1920^{* *} \\
(2.4568)\end{array}$ \\
\hline GTA/se & $\begin{array}{l}-0.0241^{*} \\
(-1.7985) \\
\end{array}$ & $\begin{array}{l}-0.0328 * * \\
(-2.1156)\end{array}$ & $\begin{array}{c}-0.0094 \\
(-0.2561) \\
\end{array}$ & $\begin{array}{c}-0.0303^{* *} \\
(-2.6157) \\
\end{array}$ \\
\hline RTA/se & $\begin{array}{l}0.1126 * \\
(1.8456) \\
\end{array}$ & $\begin{array}{l}0.1571^{*} \\
(1.6904)\end{array}$ & $\begin{array}{l}0.0917^{*} \\
(1.8205) \\
\end{array}$ & $\begin{array}{c}0.1653 * * * \\
(4.1172)\end{array}$ \\
\hline $\mathrm{DFS} / \mathrm{se}$ & $\begin{array}{c}0.0991 * * * \\
(5.3642)\end{array}$ & $\begin{array}{l}0.0762 * \\
(1.8053) \\
\end{array}$ & $\begin{array}{c}0.0512 \\
(0.4387) \\
\end{array}$ & $\begin{array}{c}0.0965^{* * *} \\
(4.0177)\end{array}$ \\
\hline IFS/se & $\begin{array}{c}-0.2610 * * * \\
(-4.1837)\end{array}$ & $\begin{array}{l}-0.1987 * * \\
(-2.6513)\end{array}$ & $\begin{array}{c}-0.1546 * * * \\
(-3.3729)\end{array}$ & $\begin{array}{c}-0.3107 * * * \\
(-5.1822)\end{array}$ \\
\hline $\mathrm{ACP} / \mathrm{se}$ & $\begin{array}{l}0.0892 * * \\
(2.5111)\end{array}$ & $\begin{array}{l}-0.0256^{*} \\
(-1.7344) \\
\end{array}$ & $\begin{array}{c}-0.3109 \\
(-0.8525)\end{array}$ & $\begin{array}{c}0.0875 * * * \\
(3.9136)\end{array}$ \\
\hline $\mathrm{CCP} / \mathrm{se}$ & $\begin{array}{l}-0.0957^{*} \\
(-1.8834)\end{array}$ & $\begin{array}{c}-0.1131^{* * *} \\
(-3.6510)\end{array}$ & $\begin{array}{c}-0.2371 \\
(-1.1549)\end{array}$ & $\begin{array}{l}-0.1084 * * \\
(-2.5963)\end{array}$ \\
\hline $\mathrm{PM} / \mathrm{se}$ & $\begin{array}{c}0.1447 * * * \\
(2.6513)\end{array}$ & $\begin{array}{l}0.2356^{*} \\
(1.8742)\end{array}$ & $\begin{array}{c}0.0966 \\
(0.8732)\end{array}$ & $\begin{array}{c}0.1801^{* * *} \\
(5.0423)\end{array}$ \\
\hline $\mathrm{PT} / \mathrm{se}$ & $\begin{array}{l}-0.1123 * * * \\
(-3.3954)\end{array}$ & $\begin{array}{c}0.1004 * * * \\
(3.5721)\end{array}$ & $\begin{array}{c}-0.0456 \\
(-0.4300)\end{array}$ & $\begin{array}{l}-0.1325^{* *} \\
(-2.7641)\end{array}$ \\
\hline OD/se & $\begin{array}{c}0.0365^{* *} \\
(2.1286) \\
\end{array}$ & $\begin{array}{l}-0.0615^{*} \\
(-1.6992) \\
\end{array}$ & $\begin{array}{c}-0.0234 \\
(-1.1016) \\
\end{array}$ & $\begin{array}{c}0.0288 * * * \\
(-4.3512) \\
\end{array}$ \\
\hline $\mathrm{AS} / \mathrm{se}$ & $\begin{array}{l}-0.1276^{*} \\
(-1.8045)\end{array}$ & $\begin{array}{l}-0.0976^{*} \\
(-1.8793)\end{array}$ & $\begin{array}{l}-0.0921^{*} \\
(-1.7635)\end{array}$ & $\begin{array}{c}-0.1159 * * * \\
(-3.6127)\end{array}$ \\
\hline NL/se & $\begin{array}{c}0.1413^{* * *} \\
(3.5621)\end{array}$ & $\begin{array}{l}-0.1275^{* *} \\
(-2.4038)\end{array}$ & $\begin{array}{l}-0.1068 * \\
(-1.9172)\end{array}$ & $\begin{array}{c}0.1391 * * * \\
(5.0020)\end{array}$ \\
\hline R-squared & 0.3826 & 0.4120 & 0.1085 & 0.4637 \\
\hline Ramsey Reset test & \multicolumn{4}{|l|}{$\begin{array}{l}F(3,765)=1.09 \\
\text { Prob }>F=0.0863^{e}\end{array}$} \\
\hline
\end{tabular}

Notes: *, **, *** denote statistical significance at $10 \%, 5 \%$ and $1 \%$ levels respectively; t-values are reported in parentheses (dependent variable: t-statistic); ${ }^{\text {a }}$ Cluster data analysis presents the MRA results with cluster-robust standard errors; ${ }^{b}$ REML presents the MRA results with restricted maximum likelihood; ${ }^{\mathrm{c}} \mathrm{MM}$ presents the MRA results with the moment estimator; ${ }^{\mathrm{d}} \mathrm{EB}$ presents the MRA results with the empirical Bayes iterative procedure; The Ramsey reset test rejects the null at all levels of statistical significance, indicating that there are no omitted non-linear terms, i.e., that there is a linear relationship in the data. 
Table 5. Meta-regression analysis with dummies for publication in academic journal and the publication year

\begin{tabular}{|c|c|c|c|c|}
\hline Moderator variables & Cluster $^{\mathrm{a}}$ & REML $^{\mathrm{b}}$ & $\mathrm{MM}^{\mathrm{C}}$ & $\mathrm{EB}^{\mathrm{d}}$ \\
\hline ANTSE=1/se & $\begin{array}{c}1.2998^{* * * *} \\
(4.1763)\end{array}$ & $\begin{array}{l}0.8826 * * \\
(2.3956)\end{array}$ & $\begin{array}{l}0.8109 * * \\
(2.7615)\end{array}$ & $\begin{array}{c}1.5128 * * * \\
(5.0679)\end{array}$ \\
\hline Intercept & $\begin{array}{c}1.0976^{* * * *} \\
(3.4150)\end{array}$ & $\begin{array}{c}1.1123 * * * \\
(3.6738)\end{array}$ & $\begin{array}{l}\text { 1.1054* } \\
\text { (1.7811) }\end{array}$ & $\begin{array}{c}1.2575 * * * \\
(3.5016)\end{array}$ \\
\hline SZ & $\begin{array}{l}-1.0971 \\
(-1.000)\end{array}$ & $\begin{array}{c}-0.7543 \\
(-1.0148)\end{array}$ & $\begin{array}{c}-0.7128 \\
(-0.9512)\end{array}$ & $\begin{array}{c}-0.5342 \\
(-1.0510)\end{array}$ \\
\hline TEXP/se & $\begin{array}{l}-0.0147 * * \\
(-2.2456)\end{array}$ & $\begin{array}{l}-0.0183^{* *} \\
(-2.5413)\end{array}$ & $\begin{array}{c}-0.0234 \\
(-1.1016)\end{array}$ & $\begin{array}{c}-0.0311^{* * *} \\
(-4.3965)\end{array}$ \\
\hline SEXP/se & $\begin{array}{l}-0.1468^{*} \\
(-1.7069)\end{array}$ & $\begin{array}{l}-0.1025^{* *} \\
(-2.3419)\end{array}$ & $\begin{array}{c}-0.1382 \\
(-0.9754)\end{array}$ & $\begin{array}{l}-0.1194 * * \\
(-2.5423)\end{array}$ \\
\hline $\mathrm{BEXP} / \mathrm{se}$ & $\begin{array}{c}-0.1086 \\
(-1.0974)\end{array}$ & $\begin{array}{c}0.2618 \\
(0.8561)\end{array}$ & $\begin{array}{c}0.1934 \\
(1.0000)\end{array}$ & $\begin{array}{l}0.0671^{*} \\
(1.6984)\end{array}$ \\
\hline NM/se & $\begin{array}{l}0.1987 * * \\
(2.7965)\end{array}$ & $\begin{array}{c}0.1100^{* * * *} \\
(3.8225)\end{array}$ & $\begin{array}{c}-0.5612 \\
(-1.3317)\end{array}$ & $\begin{array}{c}-0.2506 * * * \\
(-3.5924)\end{array}$ \\
\hline SM/se & $\begin{array}{l}-0.0262^{*} \\
(-1.8743)\end{array}$ & $\begin{array}{c}-0.0317 * * * \\
(-4.2560)\end{array}$ & $\begin{array}{c}0.0354 \\
(1.3061)\end{array}$ & $\begin{array}{c}-0.0328 * * * \\
(-3.6540)\end{array}$ \\
\hline CROSS/se & $\begin{array}{l}-0.1230^{*} \\
(-1.7804)\end{array}$ & $\begin{array}{l}-0.1067^{*} \\
(-1.9108)\end{array}$ & $\begin{array}{c}-0.0038 \\
(-1.0126)\end{array}$ & $\begin{array}{l}-0.1513^{* *} \\
(-2.6801)\end{array}$ \\
\hline PANEL/se & $\begin{array}{l}0.0097 * * \\
(2.3515)\end{array}$ & $\begin{array}{c}0.0154 \\
(1.0082)\end{array}$ & $\begin{array}{c}0.0602 \\
(-1.0000)\end{array}$ & $\begin{array}{l}0.0115 * * \\
(2.8916)\end{array}$ \\
\hline OLS/se & $\begin{array}{c}0.1143 * * * \\
(6.0271)\end{array}$ & $\begin{array}{l}0.0983^{*} \\
(1.9874)\end{array}$ & $\begin{array}{l}-0.1000^{*} \\
(-1.7219)\end{array}$ & $\begin{array}{c}0.1312 * * * \\
(4.3685)\end{array}$ \\
\hline DC*/se & $\begin{array}{l}-0.1657^{*} \\
(-1.8122)\end{array}$ & $\begin{array}{l}-0.1608^{*} \\
(-1.7517)\end{array}$ & $\begin{array}{c}-0.1421 \\
(-1.8306)\end{array}$ & $\begin{array}{l}-0.3015^{* *} \\
(-2.6111)\end{array}$ \\
\hline $\mathrm{DC} / \mathrm{se}$ & $\begin{array}{l}-0.0761 * \\
(-1.8512)\end{array}$ & $\begin{array}{l}0.0549 * \\
(1.7263)\end{array}$ & $\begin{array}{c}-0.0513 \\
(-1.0024)\end{array}$ & $\begin{array}{c}-0.0811 * * * \\
(-3.2469)\end{array}$ \\
\hline $\mathrm{NT} / \mathrm{se}$ & $\begin{array}{c}0.0456 \\
(1.0000)\end{array}$ & $\begin{array}{c}0.0182 \\
(1.0009)\end{array}$ & $\begin{array}{c}0.0329 \\
(1.1243)\end{array}$ & $\begin{array}{c}0.1125 \\
(0.7641)\end{array}$ \\
\hline $\mathrm{RT} / \mathrm{se}$ & $\begin{array}{c}0.1608 * * * \\
(3.2414)\end{array}$ & $\begin{array}{c}-0.1239 * * \\
(-2.5406)\end{array}$ & $\begin{array}{c}-0.1378 * * \\
(-2.5109)\end{array}$ & $\begin{array}{c}0.1594 * * * \\
(5.3248)\end{array}$ \\
\hline LF/se & $\begin{array}{c}-0.0895 * * * \\
(-4.1132)\end{array}$ & $\begin{array}{l}-0.0667^{*} \\
(-1.8315)\end{array}$ & $\begin{array}{c}0.1216 \\
(0.8539)\end{array}$ & $\begin{array}{c}-0.0785 * * * \\
(-3.6421)\end{array}$ \\
\hline $\mathrm{HF} / \mathrm{se}$ & $\begin{array}{c}-0.0257 * * * \\
(-3.6410)\end{array}$ & $\begin{array}{c}-0.0218 * * \\
(-2.4476)\end{array}$ & $\begin{array}{c}0.0500 \\
(1.1763)\end{array}$ & $\begin{array}{c}0.0192 * * * \\
(4.1534)\end{array}$ \\
\hline PER/se & $\begin{array}{c}-0.1233^{* *} \\
(-2.7156)\end{array}$ & $\begin{array}{c}-0.1195 * * * \\
(-3.2064)\end{array}$ & $\begin{array}{l}0.0681^{*} \\
(1.7053)\end{array}$ & $\begin{array}{c}-0.1303^{* * *} \\
(-4.1154)\end{array}$ \\
\hline FER/se & $\begin{array}{l}0.1102 * * \\
(2.6513)\end{array}$ & $\begin{array}{l}0.1058 * \\
(1.8362)\end{array}$ & $\begin{array}{c}0.0923 * * * \\
(3.7415)\end{array}$ & $\begin{array}{c}0.1064 * \\
(1.8972)\end{array}$ \\
\hline GTA/se & $\begin{array}{c}-0.1149 \\
(-1.0007)\end{array}$ & $\begin{array}{l}-0.0688^{*} \\
(-1.7954)\end{array}$ & $\begin{array}{c}0.1135 \\
(1.1000)\end{array}$ & $\begin{array}{c}-0.0976 * * * \\
(-4.2815)\end{array}$ \\
\hline RTA/se & $\begin{array}{c}0.0876^{* * * *} \\
(3.5501)\end{array}$ & $\begin{array}{l}0.0601^{* *} \\
(2.4438)\end{array}$ & $\begin{array}{c}0.0505 \\
(0.3419)\end{array}$ & $\begin{array}{l}0.0803 * * \\
(2.6419)\end{array}$ \\
\hline DFS/se & $\begin{array}{l}0.1125^{*} \\
(1.9032)\end{array}$ & $\begin{array}{l}0.0854^{*} \\
(1.7312)\end{array}$ & $\begin{array}{c}0.0632 \\
(1.2810)\end{array}$ & $\begin{array}{c}0.0924 * * * \\
(3.2608)\end{array}$ \\
\hline IFS/se & $\begin{array}{l}-0.1768^{*} \\
(-1.9431)\end{array}$ & $\begin{array}{c}-0.1305^{* *} \\
(-2.5907)\end{array}$ & $\begin{array}{c}0.0881 \\
(1.4715)\end{array}$ & $\begin{array}{l}-0.1792^{* *} \\
(-2.6311)\end{array}$ \\
\hline
\end{tabular}




\begin{tabular}{|l|c|c|c|c|}
\hline ACP/se & $-0.1017^{* * *}$ & $-0.0845^{*}$ & $-0.0661^{*}$ & $0.1203^{*}$ \\
& $(-4.8329)$ & $(-1.8357)$ & $(-1.7695)$ & $(1.8234)$ \\
\hline CCP/se & $-0.1765^{*}$ & -0.2519 & -0.1083 & $-0.1825^{* * *}$ \\
& $(-1.9923)$ & $(-1.1376)$ & $(-0.1695)$ & $(-3.7349)$ \\
\hline PM/se & $0.1286^{*}$ & $0.0985^{* *}$ & 0.0754 & $0.0826^{* * *}$ \\
& $(1.8053)$ & $(2.3174)$ & $(1.0102)$ & $(4.3895)$ \\
\hline PT/se & $-0.1567^{* *}$ & $0.1215^{*}$ & 0.0872 & $-0.1581^{*}$ \\
& $(-2.8019)$ & $(1.8235)$ & $(0.9651)$ & $(-1.9146)$ \\
\hline OD/se & $-0.0671^{* * *}$ & $-0.0423^{* *}$ & -0.1269 & $0.0455^{* *}$ \\
& $(-4.5423)$ & $(-2.3862)$ & $(-1.0004)$ & $(2.7120)$ \\
\hline AS/se & $-0.1019^{* * *}$ & $-0.0786^{* *}$ & 0.1819 & $-0.1157^{* *}$ \\
& $(-3.6234)$ & $(-2.2514)$ & $(1.0123)$ & $(-2.6329)$ \\
\hline NL/se & $0.0761^{*}$ & $-0.0518^{* * *}$ & $0.0634^{* *}$ & $0.0810^{* * *}$ \\
& $(1.8235)$ & $(-4.2867)$ & $(-2.2059)$ & $(3.6124)$ \\
\hline AJ/se & $-0.0234^{* * *}$ & $-0.0210^{*}$ & 0.0069 & $-0.0351^{* * *}$ \\
& $(-3.5672)$ & $(-1.7958)$ & $(0.8711)$ & $(-4.7248)$ \\
\hline PUBY/se & 0.0307 & -0.0094 & 0.0606 & 0.1569 \\
& $(1.0000)$ & $(-1.2916)$ & $(0.9710)$ & $(1.3472)$ \\
\hline R-squared & 0.4015 & 0.4198 & 0.1976 & 0.4537 \\
\hline Ramsey Reset test & $\mathrm{F}(3,765)=1.13$ & & & \\
& Prob>F=0.0904 & & & \\
\hline
\end{tabular}

Notes: ${ }^{*}, * *, * *$ denote statistical significance at 10\%, 5\% and 1\% levels respectively; t-values are reported in parentheses (dependent variable: t-statistic); ${ }^{a}$ Cluster data analysis presents the MRA results with cluster-robust standard errors; ${ }^{\mathrm{b}}$ REML presents the MRA results with restricted maximum likelihood; ${ }^{\mathrm{c}} \mathrm{MM}$ presents the MRA results with the moment estimator; ${ }^{\mathrm{d}} \mathrm{EB}$ presents the MRA results with the empirical Bayes iterative procedure; The Ramsey reset test rejects the null at all levels of statistical significance, indicating that there are no omitted non-linear terms, i.e., that there is a linear relationship in the data.

Table 6. Meta- regression analysis (considering working papers and publications in academic journals): Cluster data analysis

\begin{tabular}{|l|c|c|}
\hline Moderator variables & Total exports studies & Sectoral exports studies \\
\hline ANTSE=1/se & 1.0321 & $1.4005^{* *}$ \\
& $(0.5892)$ & $(2.8914)$ \\
\hline Intercept & $1.3467^{* * *}$ & 0.3652 \\
& $(5.1289)$ & $(0.8916)$ \\
\hline SZ & 0.6754 & -0.2456 \\
& $(1.0973)$ & $(-0.5582)$ \\
\hline NM/se & $0.2345^{*}$ & 0.2915 \\
& $(1.8671)$ & $(0.8762)$ \\
\hline SM/se & $-0.1345^{* * *}$ & $-0.2657^{* *}$ \\
& $(-6.217)$ & $(-3.8954)$ \\
\hline CROSS/se & $-0.0810^{* * *}$ & 0.9318 \\
& $(-3.7621)$ & $(1.4261)$ \\
\hline PANEL/se & 0.0195 & 0.0086 \\
& $(0.8724)$ & $(1.1453)$ \\
\hline OLS/se & $0.0946^{* * *}$ & -2.2162 \\
& $(3.8742)$ & $(-1.5313)$ \\
\hline DC*/se & $-0.3425^{* *}$ & 0.6318 \\
& $(-2.6579)$ & $(0.2357)$ \\
\hline
\end{tabular}




\begin{tabular}{|c|c|c|}
\hline $\mathrm{DC} / \mathrm{se}$ & $\begin{array}{l}-0.1128 * * \\
(-2.6093)\end{array}$ & $\begin{array}{l}-0.2179 * * * \\
(-4.2681)\end{array}$ \\
\hline NT/se & $\begin{array}{l}-0.1562 * * \\
(-3.0198)\end{array}$ & $\begin{array}{l}-0.0956 * * * \\
(-4.4342)\end{array}$ \\
\hline $\mathrm{RT} / \mathrm{se}$ & $\begin{array}{l}0.1981^{* * *} \\
(5.1247)\end{array}$ & $\begin{array}{l}0.1366^{* *} \\
(2.3519)\end{array}$ \\
\hline $\mathrm{LF} / \mathrm{se}$ & $\begin{array}{c}0.3876 \\
(1.0954)\end{array}$ & $\begin{array}{c}0.1054 \\
(0.9213)\end{array}$ \\
\hline $\mathrm{HF} / \mathrm{se}$ & $\begin{array}{l}0.1123 * \\
(1.8542)\end{array}$ & $\begin{array}{l}-0.1508 * * * \\
(-4.2450)\end{array}$ \\
\hline PER/se & $\begin{array}{l}-0.1013^{*} \\
(-1.9485)\end{array}$ & $\begin{array}{c}0.4818 \\
(0.6231)\end{array}$ \\
\hline FER/se & $\begin{array}{l}0.1604 * * * \\
(3.2875)\end{array}$ & $\begin{array}{l}0.2178^{*} \\
(1.9310)\end{array}$ \\
\hline GTA/se & $\begin{array}{c}-0.3421^{* *} \\
(-2.5649)\end{array}$ & $\begin{array}{c}0.2156 \\
(0.8967)\end{array}$ \\
\hline RTA/se & $\begin{array}{c}0.1542 * * * \\
(4.3061)\end{array}$ & $\begin{array}{c}0.5260 \\
(0.1331)\end{array}$ \\
\hline DFS/se & $\begin{array}{c}0.0873^{* * *} \\
(3.8125)\end{array}$ & $\begin{array}{l}0.1249 * \\
(2.1125)\end{array}$ \\
\hline IFS/se & $\begin{array}{c}-0.2610 * * * \\
(-4.1837)\end{array}$ & $\begin{array}{l}-0.1731^{*} \\
(-1.9143) \\
\end{array}$ \\
\hline $\mathrm{ACP} / \mathrm{se}$ & $\begin{array}{l}0.1876 * \\
(1.8653)\end{array}$ & $\begin{array}{l}0.1182 * \\
(2.0120)\end{array}$ \\
\hline $\mathrm{CCP} / \mathrm{se}$ & $\begin{array}{l}-0.0957^{*} \\
(-1.8834)\end{array}$ & $\begin{array}{l}-0.1104^{* *} \\
(-2.0095)\end{array}$ \\
\hline $\mathrm{PM} / \mathrm{se}$ & $\begin{array}{l}0.2541^{* *} \\
(2.8327)\end{array}$ & $\begin{array}{c}0.1894 * * * \\
(4.3202)\end{array}$ \\
\hline $\mathrm{PT} / \mathrm{se}$ & $\begin{array}{l}-0.2135^{* *} \\
(-2.2671)\end{array}$ & $\begin{array}{l}-0.1732 * * * \\
(-3.3365)\end{array}$ \\
\hline OD/se & $\begin{array}{l}0.1123^{* *} \\
(2.6429)\end{array}$ & $\begin{array}{l}0.1944^{*} \\
(1.7820)\end{array}$ \\
\hline $\mathrm{AS} / \mathrm{se}$ & $\begin{array}{c}-0.2019 * * * \\
(-3.6794)\end{array}$ & $\begin{array}{l}-0.2398 * * \\
(-2.5834)\end{array}$ \\
\hline NL/se & $\begin{array}{l}-0.1253^{* *} \\
(-2.7164)\end{array}$ & $\begin{array}{c}-0.1027 \\
(-0.8419) \\
\end{array}$ \\
\hline R-squared & 0.5127 & 0.2314 \\
\hline $\begin{array}{l}\text { Ramsey RESET test } \\
\mathrm{H}_{0} \text { : No omitted variables }\end{array}$ & $\begin{array}{l}F(3,608)=1.43 \\
\text { Prob }>F=0.1947\end{array}$ & $\begin{array}{l}F(3,511)=0.89 \\
\text { Prob }>F=0.2345\end{array}$ \\
\hline
\end{tabular}

Notes: *, **, $* * *$ denote statistical significance at $10 \%, 5 \%$ and $1 \%$ levels respectively; t-values are reported in parentheses (dependent variable: t-statistic, i.e. the effect size of exchange rate volatility on trade); Cluster data analysis presents the MRA results with cluster-robust standard errors; The Ramsey reset test rejects the null at all levels of statistical significance, indicating that there are no omitted non-linear terms, i.e., that there is a linear relationship in the data. 
Table 7. Meta-regression analysis with dummies for publication in academic journal and the publication year: Cluster data analysis

\begin{tabular}{|c|c|c|}
\hline Moderator variables & Total exports studies & Sectoral exports studies \\
\hline ANTSE $=1 / \mathrm{se}$ & $\begin{array}{c}0.7621 \\
(1.1345)\end{array}$ & $\begin{array}{c}0.9352 * * * \\
(4.1357)\end{array}$ \\
\hline Intercept & $\begin{array}{c}0.7642 * * * \\
(6.1123)\end{array}$ & $\begin{array}{c}1.1345 \\
(0.2872)\end{array}$ \\
\hline SZ & $\begin{array}{l}0.0352 \\
(1.000)\end{array}$ & $\begin{array}{c}0.1823 \\
(1.1574)\end{array}$ \\
\hline NM/se & $\begin{array}{l}0.2716 * * \\
(3.0155)\end{array}$ & $\begin{array}{c}0.1421 \\
(1.5219)\end{array}$ \\
\hline SM/se & $\begin{array}{c}-0.1610^{* *} \\
(-2.837)\end{array}$ & $\begin{array}{c}-0.2134^{* * *} \\
(-4.106)\end{array}$ \\
\hline CROSS/se & $\begin{array}{c}-0.1324 * * * \\
(-3.5864)\end{array}$ & $\begin{array}{c}0.5678 \\
(0.9210)\end{array}$ \\
\hline PANEL/se & $\begin{array}{c}0.1013 \\
(1.2567)\end{array}$ & $\begin{array}{c}0.1612 \\
(1.3895)\end{array}$ \\
\hline OLS/se & $\begin{array}{c}0.1218^{* *} \\
(2.7120)\end{array}$ & $\begin{array}{l}0.8651 \\
(1.145)\end{array}$ \\
\hline $\mathrm{DC} * / \mathrm{se}$ & $\begin{array}{c}-0.2912 * * * \\
(-5.1196)\end{array}$ & $\begin{array}{c}-0.9756 \\
(-1.5510)\end{array}$ \\
\hline DC/se & $\begin{array}{c}-0.2013 * * * \\
(-3.8419)\end{array}$ & $\begin{array}{l}-0.2561^{*} \\
(-1.9652)\end{array}$ \\
\hline NT/se & $\begin{array}{c}-0.0891 * * * \\
(-4.1045)\end{array}$ & $\begin{array}{l}-0.1132^{*} \\
(-1.8251)\end{array}$ \\
\hline RT/se & $\begin{array}{c}0.1012 * * * \\
(3.2896)\end{array}$ & $\begin{array}{c}0.1157 * * * \\
(4.1132)\end{array}$ \\
\hline LF/se & $\begin{array}{c}-1.3648 \\
(-0.7201)\end{array}$ & $\begin{array}{c}0.5934 \\
(0.6128)\end{array}$ \\
\hline $\mathrm{HF} / \mathrm{se}$ & $\begin{array}{c}0.1019 * * \\
(1.8913)\end{array}$ & $\begin{array}{l}-0.2137^{*} \\
(-1.9216)\end{array}$ \\
\hline PER/se & $\begin{array}{c}-0.0765 * * * \\
(-3.3924)\end{array}$ & $\begin{array}{c}0.1611 \\
(1.2548)\end{array}$ \\
\hline FER/se & $\begin{array}{c}0.1215^{* * *} \\
(4.0982)\end{array}$ & $\begin{array}{l}0.1546^{*} \\
(1.8721)\end{array}$ \\
\hline GTA/se & $\begin{array}{c}-0.2831^{* *} \\
(-3.8547)\end{array}$ & $\begin{array}{c}-0.5167 \\
(-1.4310)\end{array}$ \\
\hline RTA/se & $\begin{array}{c}0.1410 * * * \\
(3.8715)\end{array}$ & $\begin{array}{c}0.4895 \\
(1.2876) \\
\end{array}$ \\
\hline DFS/se & $\begin{array}{c}0.0873^{*} \\
(2.6194)\end{array}$ & $\begin{array}{c}0.0654 * * * \\
(4.6723)\end{array}$ \\
\hline IFS/se & $\begin{array}{c}-0.2543 * * * \\
(-3.6132)\end{array}$ & $\begin{array}{c}-0.1984 * * \\
(-2.5663)\end{array}$ \\
\hline $\mathrm{ACP} / \mathrm{se}$ & $\begin{array}{c}0.1016^{* *} \\
(2.4652)\end{array}$ & $\begin{array}{c}0.0485 * \\
(1.7316) \\
\end{array}$ \\
\hline $\mathrm{CCP} / \mathrm{se}$ & $\begin{array}{l}-0.1234^{*} \\
(-1.7618)\end{array}$ & $\begin{array}{c}-0.0967 * * * \\
(-3.5618)\end{array}$ \\
\hline $\mathrm{PM} / \mathrm{se}$ & $\begin{array}{c}0.2712 * * * \\
(3.6438)\end{array}$ & $\begin{array}{l}0.2359 * \\
(3.8321)\end{array}$ \\
\hline
\end{tabular}




\begin{tabular}{|l|c|c|}
\hline PT/se & $-0.1415^{* * *}$ & $-0.1814^{*}$ \\
& $(-5.1382)$ & $(-2.1652)$ \\
\hline OD/se & $0.1229^{*}$ & $0.1324^{*}$ \\
& $(1.7394)$ & $(1.9210)$ \\
\hline AS/se & $-0.1694^{* *}$ & $-0.1824^{*}$ \\
& $(-2.8101)$ & $(-1.9312)$ \\
\hline NL/se & $-0.1018^{* * *}$ & 0.1386 \\
& $(-3.9315)$ & $(1.5910)$ \\
\hline AJ/se & $-0.0972^{* * *}$ & $-0.1910 * * *$ \\
& $(-3.6359)$ & $(-4.7958)$ \\
\hline PUBY/se & 0.2147 & 0.1567 \\
& $(1.1319)$ & 0.3178 \\
\hline R-squared & 0.5513 & $\mathrm{~F}(3,511)=1.13$ \\
\hline Ramsey RESET test & $\mathrm{F}(3,608)=1.65$ & Prob $>\mathrm{F}=0.2512$ \\
Ho & Prob $>\mathrm{F}=0.2369$ & $\mathrm{c}$. \\
\hline
\end{tabular}

Notes: *,**,** denote statistical significance at $10 \%, 5 \%$ and $1 \%$ levels respectively; t-values are reported in parentheses (dependent variable: t-statistic, i.e. the effect size of exchange rate volatility on trade); Cluster data analysis presents the MRA results with cluster-robust standard errors; The Ramsey reset test rejects the null at all levels of statistical significance, indicating that there are no omitted non-linear terms, i.e., that there is a linear relationship in the data. 